\title{
Crystal structures and constitution of the binary system iridium-boron
}

\author{
Isolde Zeiringer ${ }^{1 \dagger}$, Xiyue Cheng ${ }^{2 \dagger}$, Xing-Qiu Chen ${ }^{2 *}$, Ernest Bauer ${ }^{3}$, Gerald Giester $^{4}$ and \\ Peter Franz Rog $1^{1^{*}}$
}

The constitution of the binary system Ir-B has been established between 10 and 70 at.\% boron for temperatures above $700^{\circ} \mathrm{C}$ based on differential scanning calorimetry, electron probe microanalysis, and isothermal low temperature annealing experiments $\left(\leqslant 1000^{\circ} \mathrm{C}\right)$. Four binary phases have been found, namely $\operatorname{Ir}_{4} B_{5+x}, \operatorname{Ir}_{5} B_{4+x}$ and the high and low temperature modification of $\operatorname{Ir}_{4} \mathrm{~B}_{3-x}$. X-ray structure analyses were performed on single crystals of $\operatorname{Ir}_{4} B_{5+x}\left(x=0, \operatorname{Ir}_{4} B_{5}\right.$ type; space group $C 2 / m ; a=1.05200(2), b=0.289564(6)$ and $c=0.60958(1) \mathrm{nm}$, $\left.\beta=91.156(2)^{\circ}\right), \operatorname{Ir}_{5} B_{4+x}\left(x=0, \operatorname{Ir}_{5} B_{4}\right.$ type; space group $I 4_{1} / a ; a=$ $0.62777(1)$ and $b=1.02599(2) \mathrm{nm})$ and on the low temperature modification of $\operatorname{Ir}_{4} B_{3-x}\left(x=0, \operatorname{IrB}_{0.9}\right.$ type; space group $C m c 2_{1}$; $a$ $=0.27728(1), b=0.75742(2)$ and $c=0.73152(2) \mathrm{nm})$. The high temperature modification of $\operatorname{Ir}_{4} B_{3-x}$ (WC type; space group $P \overline{6} m 2 ; a=0.28137(5)$ and $c=0.2828(1) \mathrm{nm}$ ) has been confirmed by X-ray powder diffraction. By means of the first-principle calculations, in combination with the evolutionary structural search algorithm, the compositions, structures and enthalpies of the Ir-B system have been investigated theoretically. Confirming the experimental observations on $\operatorname{Ir}_{4} B_{5}, \operatorname{Ir}_{5} B_{4}$ and $\operatorname{Ir}_{4} B_{3}$, we have investigated several metastable phases at other stoichiometries, such as $\operatorname{IrB}, \operatorname{IrB}_{2}$ and $\operatorname{Ir}_{3} B_{2}$. We also proposed three thermodynamically and dynamically stable new structures of $o F 28-\operatorname{Ir}_{4} \mathrm{~B}_{3}, o C 8$-IrB and $m C 10-\operatorname{Ir}_{3} \mathrm{~B}_{2}$, which may be synthesized under certain conditions.

\section{INTRODUCTION}

The search for superhard and/or incompressible materials has led to a renewed research interest in binary transition metal borides especially on those with the highest boron contents [1]. For example, $\mathrm{W}_{1-x} \mathrm{~B}_{3}$ possesses a load independent Vickers hardness of $31.8 \mathrm{GPa}$ (but $46.2 \mathrm{GPa}$ at 0.5 $\mathrm{N}$ and $36.7 \mathrm{GPa}$ at $1 \mathrm{~N}[2]$ ) and polycrystalline $\mathrm{ReB}_{2}$ exceeds an average load independent Vickers hardness of about 30
$\mathrm{GPa}[2](48 \mathrm{GPa}(0.5 \mathrm{~N})[3])$ or $26.6 \mathrm{GPa}(39.3 \mathrm{GPa}(0.5 \mathrm{~N}))$ [2] with rather different hardness values due to the anisotropic crystal structure (for details on the crystal structure of $\mathrm{W}_{1-x} \mathrm{~B}_{3}$, see [4]). Vicker's hardness measurements on the boron richest iridium boride $\operatorname{IrB}_{1.35}$ revealed a load independent value of 18.2 GPa (at 9.81 N) but $49.8 \mathrm{GPa}$ at $0.49 \mathrm{~N}$ [5] and at such low loads the hardness is therefore comparable with bulk samples of $\mathrm{ReB}_{2}$. Quite high hardness values were also recorded for $\operatorname{IrB}_{1.1}$ thin films (on $\mathrm{SiO}_{2}$ substrate) revealing an intrinsic film hardness of $43( \pm 5)$ GPa [6].

Investigations on the constitution of the binary system Ir-B revealed the existence of three compounds $\operatorname{Ir}_{3} B_{2}, \operatorname{IrB}$ and $\mathrm{IrB}_{2}$ [7-9]. Some of the early reports were mainly concerned with the metal-rich eutectic $\left(1046^{\circ} \mathrm{C}\right.$ at 21.4 at.\% $\mathrm{B}$ [10]), with the optimization of synthesis techniques [8] and with the stability of $\mathrm{IrB}_{1.1}$ against various acids and bases [11]. Melting point $\left(T_{\mathrm{m}}=1190 \pm 20^{\circ} \mathrm{C}\right)$, microhardness $1652 \pm 80 \mathrm{kgf} / \mathrm{mm}^{2}$, Seebeck coefficient $\left(20-800^{\circ} \mathrm{C}, S_{\mathrm{V}}\right.$, $m i n$ $=-9 \mu \mathrm{V} / \mathrm{K}$ at $\left.350^{\circ} \mathrm{C}\right)$ and electrical resistance $\left(20-800^{\circ} \mathrm{C}\right)$ for $\operatorname{IrB}_{1.1}$ were reported by Samsonov et al. [8]. X-ray powder and single crystal (Weissenberg) photographs served to evaluate the crystal structure of $\operatorname{IrB}_{1.1}$, which was reported to be isotypic with the $\alpha-\mathrm{ThSi}_{2}$ structure type (space group $I 4_{1} /$ amd; $a=0.2810, c=1.0263 \mathrm{~nm}$ ) exhibiting a severe defect at the boron sites (8e sites randomly occupied by $~ 50 \%$ of $\mathrm{B}$ atoms) [12]. For the compound richest in boron, ' $\mathrm{IrB}_{2}$ ', monoclinic symmetry (space group $\mathrm{C} 2 / \mathrm{m}$ ) was established from X-ray single crystal multi-film Weissenberg photographs yielding a crystal structure described as a stacking of puckered boron layers (A) and puckered double layers of metal atoms $(\mathrm{B})$ in the simple sequence $\mathrm{ABAB}$ in $c$-direc-

\footnotetext{
${ }^{1}$ Institute of Materials Chemistry and Research, University of Vienna, A-1090 Wien, Austria

${ }^{2}$ Shenyang National Laboratory for Materials Science (SYNL), Institute of Metal Research (IMR), Chinese Academy of Sciences (CAS), Shenyang 110016, China

${ }^{3}$ Institute of Solid State Physics, Vienna University of Technology, A-1040 Wien, Austria

${ }^{4}$ Institute of Mineralogy and Crystallography, University of Vienna, A-1090 Wien, Austria

${ }^{\dagger}$ These authors contributed to this work equally.

*Corresponding authors (emails: peter.franz.rogl@univie.ac.at (Rogl PF); xingqiu.chen@imr.ac.cn (Chen XQ))
} 
tion [13]. Due to boron defects in two of the four B-sites, a formula of $\operatorname{IrB}_{1.35}$ was derived. A reinvestigation of the structure employing X-ray single crystal data from an automatic diffractometer by Lundström et al. [14] confirmed the monoclinic symmetry (space group $C 2 / m ; a \sim 1.053, b$ $\sim 0.290, c \sim 0.610 \mathrm{~nm}$ and $\left.\beta=91.1^{\circ}\right)$, but suggested Ir-atoms off the mirror plane in the general position $8 j(x, y, z)$ with an occupation of $1 / 2$. Difference Fourier maps furthermore gave hints for only 3 boron positions instead of 4 with one of them only half occupied. The corresponding composition was thus close to $\operatorname{Ir}_{4} \mathrm{~B}_{5}$.

For the third iridium-boride, ' $\mathrm{Ir}_{3} \mathrm{~B}_{2}$ ', richest in $\mathrm{Ir}$, it is interesting to note that the $\mathrm{X}$-ray powder photograph obtained by Haschke at $1200^{\circ} \mathrm{C}$ (labelled as ' $\operatorname{Ir}_{\sim 1.2} \mathrm{~B}$ ', [15]) showed remarkable differences to that one, for which Brukl et al. [9] reported $\sin ^{2} q$ values. Obviously a low- and high-temperature modification exist, the crystal structures of which were determined by Rogl et al. [16]. The high temperature modification (labelled ' $\mathrm{IrB}_{0.9}$ ', WC type; space group $P \overline{6} \mathrm{~m} 2 ; a=0.2815, c=0.2823 \mathrm{~nm}$ ) was observed above $1200^{\circ} \mathrm{C}$, whereas the low temperature modification was described with a unique structure type (space group $C m 2_{1}$; $a=0.2771, b=0.7578, c=0.7314 \mathrm{~nm}$; from $\mathrm{X}$-ray single crystal multi-film Weissenberg photographs, $\left.R_{\mathrm{F}}=0.07\right)$. Vandenberg et al. [17] searched for superconductivity in the high temperature modification, but the alloy remained normal down to $1.28 \mathrm{~K}$.

Theoretical studies of $\operatorname{IrB}$ and $\operatorname{IrB}_{2}$ using first principle calculations [18] revealed a hexagonal structure (space group $P 6_{3} / \mathrm{mmm}$; $a \sim 0.35, c \sim 0.39 \mathrm{~nm}$ ) to be elastically stable for IrB and a stable orthorhombic structure for $\operatorname{IrB}_{2}$ (space group Pmmn; $a \sim 0.31 ; b \sim 0.45, c \sim 0.40 \mathrm{~nm}$ ). In a later work, Wang et al. [19] predicted also an orthorhombic structure for IrB (space group Pnma; $a \sim 0.443, b \sim 0.287$ and $c \sim 0.702 \mathrm{~nm}$ ), whilst $\mathrm{IrB}_{2}$ was said to be isotypic with $\mathrm{OsB}_{2}$ (space group Pmmn; $a \sim 0.315, b \sim 0.445$ and $c \sim 0.404$ $\mathrm{nm})[19,20]$. The calculations considered a series of alternative structure types: $\mathrm{CsCl}, \mathrm{FeB}, \mathrm{WC}$, anti-NiAs, as well as $\mathrm{AlB}_{2}, \mathrm{ReB}_{2}, \mathrm{WB}_{2}$. Among all these structures orthorhombic IrB (space group Pnma; $a \sim 0.443, b \sim 0.287$ and $c \sim 0.702$ $\mathrm{nm}$ ) and $\mathrm{IrB}_{2}$ with the $\mathrm{OsB}_{2}$-type were found to be dynamically and mechanically stable. At a pressure of about $5 \mathrm{GPa}$ orthorhombic IrB was said to undergo a phase transition to the anti-NiAs phase. In another theoretical study [21] on the $4 \mathrm{~d}$ and $5 \mathrm{~d}$ transition metal monoborides, $\operatorname{IrB}$ with WC crystal structure has been found to be thermodynamically stable at zero pressure. From the calculation, stoichiometric IrB is mechanically unstable, indicating together with the difference in experimental and calculated lattice parameters, the presence of boron vacancies in the crystal structure.

First experimental studies concerning the binary Ir-B phase diagram have been carried out by Reinacher on a hot stage microscope under argon [10]. He reports a very low melting eutectic at $1046^{\circ} \mathrm{C}$ on the iridium rich side ( 21 at.\% B). Brukl and Rudy [9] established the first binary phase diagram on the basis of metallography, X-ray powder diffraction (XPD) and pyrometric melting point data employing the Pirani method. Later, Spear [22] predicted a phase diagram on the basis of some intermediate phases, which, however, is not in good agreement with the crystallographic findings. Isothermal reactions, reported in the literature, are summarized in Table 1. Ipser and Rogl [23] published invariant reaction temperatures and liquidus temperatures for the binary system and the complete phase diagram in the range from 20 to 70 at.\% boron has been reported by Rogl [24]. Based on this phase diagram evaluation, Zivkovic et al. [25] estimated the thermodynamic activities in the liquid state at $2800 \mathrm{~K}, 2900 \mathrm{~K}$ and $3000 \mathrm{~K}$ for $0<x_{\mathrm{Ir}}<0.35$ and $0.6<x_{\mathrm{Ir}}<1.0$ (regular solution approach). For $\operatorname{IrB}_{1.35}$, the standard enthalpy of formation $\left(\Delta H_{\mathrm{f}}^{0}=\right.$ $-49.1 \pm 2.4 \mathrm{~kJ} \mathrm{~mol}^{-1}$ ) has been derived by Meschel and Kleppa [26] from direct synthesis calorimetry at $1200^{\circ} \mathrm{C}$. A high temperature mass spectrometric study reported a stable gaseous monoboride IrB and prompted the dissociation energy $\left(D_{\mathrm{O}}^{0}=508.5 \pm 17 \mathrm{~kJ} \mathrm{~mol}^{-1} \operatorname{IrB}(\mathrm{g})\right)$ as well as the heat of formation $\delta H_{\mathrm{O}}^{0}\left(3^{\text {rd }}\right.$ law) $=43.6 \mathrm{~kJ} \mathrm{~mol}^{-1}$ for 'IrB' (structure not specified) [27].

As there still remained open questions concerning crystal structures and especially the composition of the reported phases, the aim of this work was (i) to reinvestigate the crystal structures of the Ir-B phases by X-ray single crystal and powder diffraction analyses, (ii) to define their compositions with wavelength dispersive X-ray (WDX) electron probe microanalysis, (iii) to re-evaluate the constitution of the binary phase diagram on the basis of differential scanning calorimetry, XPD as well as by electron probe microanalysis and furthermore (iv) to evaluate all structures and enthalpies of compounds of the Ir-B system employing first-principle calculations in combination with the evolutionary structural search algorithm.

\section{EXPERIMENTAL DETAILS}

\section{Synthesis and characterization of alloys}

Proper blends of powders of iridium (purity 99.99\%) and crystalline boron (purity 98-99\%) were carefully mixed, cold-compacted to pellets without lubricants and melted in an arc furnace under argon at least three times to ensure homogeneity. The arc-melted buttons were cut into pieces, 
Table 1 Isothermal reactions in the binary Ir-B system reported in literature

\begin{tabular}{|c|c|c|c|}
\hline Reaction type: temperature $\left({ }^{\circ} \mathrm{C}\right)$ & Reaction & B content (at.\%) & Ref. \\
\hline \multirow[t]{2}{*}{ Eutectic: $1259 \pm 4$} & $\mathrm{~L} \leftrightarrow(\operatorname{Ir})+\operatorname{IrB}_{0.7}$ & 37.5 & [23] \\
\hline & $\mathrm{L} \leftrightarrow(\mathrm{Ir})+\operatorname{IrB}_{1-x}$ & & [24] \\
\hline Eutectic: 1046 & $\mathrm{L} \leftrightarrow(\mathrm{Ir})+\operatorname{IrB}_{1-x}$ & 21 & {$[10]$} \\
\hline Eutectic: $1250 \pm 6$ & $\mathrm{~L} \leftrightarrow(\mathrm{Ir})+\mathrm{Ir}_{3} \mathrm{~B}_{2}$ & $36 \pm 1$ & [9] \\
\hline Eutectic: 1045 & $\mathrm{L} \leftrightarrow(\mathrm{Ir})+\operatorname{IrB}_{1-x}$ & $\sim 35$ & [22] \\
\hline \multirow[t]{2}{*}{ Congruent melting: $1287 \pm 5$} & $\mathrm{~L} \leftrightarrow \operatorname{IrB}_{0.7}$ & 38.5 & [23] \\
\hline & $\mathrm{L} \leftrightarrow \operatorname{IrB}_{1-x}$ & & [24] \\
\hline Congruent melting: $1270 \pm 20$ & $\mathrm{~L} \leftrightarrow \mathrm{Ir}_{3} \mathrm{~B}_{2}$ & $\sim 40$ & [9] \\
\hline Congruent melting: $\sim 1057$ & $\mathrm{~L} \leftrightarrow \mathrm{IrB}_{1-x}$ & $\sim 38.5$ & [22] \\
\hline \multirow[t]{2}{*}{ Eutectic: $1258 \pm 5$} & $\mathrm{~L} \leftrightarrow \operatorname{IrB}_{0.7}+\operatorname{IrB}_{0.9}$ & $\sim 40$ & [23] \\
\hline & $\mathrm{L} \leftrightarrow \operatorname{IrB}_{1-x}+\operatorname{IrB}_{2-x}$ & & [24] \\
\hline Eutectic: $1238 \pm 8$ & $\mathrm{~L} \leftrightarrow \mathrm{Ir}_{3} \mathrm{~B}_{2}+\mathrm{IrB}_{0.89}$ & $\sim 43$ & [9] \\
\hline Eutectic: $~ 917$ & $\mathrm{~L} \leftrightarrow \operatorname{IrB}_{1-x}+\operatorname{IrB}_{2-x}$ & $\sim 44$ & [22] \\
\hline \multirow[t]{2}{*}{ Congruent melting: $1333 \pm 5$} & $\mathrm{~L} \leftrightarrow \mathrm{IrB}_{0.9}$ & 46.5 & [23] \\
\hline & $\mathrm{L} \leftrightarrow \operatorname{IrB}_{2-x}$ & & [24] \\
\hline Congruent melting: $1328 \pm 10$ & $\mathrm{~L} \leftrightarrow \mathrm{IrB}_{0.89}$ & $\sim 47$ & [9] \\
\hline Congruent melting: 1093 & $\mathrm{L} \leftrightarrow \operatorname{IrB}_{2-x}$ & $\sim 49$ & [22] \\
\hline \multirow[t]{2}{*}{ Peritectic: $1274 \pm 5$} & $\mathrm{~L}+\mathrm{IrB}_{0.9} \leftrightarrow \mathrm{IrB}$ & 50 & [23] \\
\hline & $\mathrm{L}+\mathrm{IrB} \mathrm{B}_{2-x} \leftrightarrow \mathrm{IrB}$ & & [24] \\
\hline \multirow[t]{2}{*}{ Eutectoid: $1209 \pm 3$} & $\operatorname{IrB} \leftrightarrow \operatorname{IrB}_{0.9}+\operatorname{IrB}_{1.35}$ & \multirow{2}{*}{50} & [23] \\
\hline & $\operatorname{IrB} \leftrightarrow \operatorname{IrB}_{2-x}+\operatorname{Ir}_{4} B_{5}$ & & [24] \\
\hline \multirow[t]{2}{*}{ Eutectic: $1248 \pm 3$} & $\mathrm{~L} \leftrightarrow \operatorname{IrB}+\operatorname{IrB}_{1.35}$ & \multirow[t]{2}{*}{54} & [23] \\
\hline & $\mathrm{L} \leftrightarrow \mathrm{IrB}+\mathrm{Ir}_{4} \mathrm{~B}_{5}$ & & [24] \\
\hline Eutectic: $1250 \pm 10$ & $\mathrm{~L} \leftrightarrow \mathrm{IrB}_{0.89}+\operatorname{IrB}_{1.5}$ & 51 & [9] \\
\hline \multirow{2}{*}{ Metastable eutectic: 1235} & $\mathrm{~L} \leftrightarrow \mathrm{IrB}_{0.9}+\mathrm{IrB}_{1.35}$ & \multirow{2}{*}{53} & [23] \\
\hline & $\mathrm{L} \leftrightarrow \mathrm{IrB}_{2-x}+\mathrm{Ir}_{4} \mathrm{~B}_{5}$ & & [24] \\
\hline \multirow[t]{2}{*}{ Congruent melting: $1287 \pm 5$} & $\mathrm{~L} \leftrightarrow \operatorname{IrB}_{1.35}$ & 57.5 & [23] \\
\hline & $\mathrm{L} \leftrightarrow \mathrm{Ir}_{4} \mathrm{~B}_{5}$ & & [24] \\
\hline Congruent melting: $1315 \pm 15$ & $\mathrm{~L} \leftrightarrow \operatorname{IrB}_{1.5}$ & $\sim 60$ & [9] \\
\hline \multirow[t]{2}{*}{ Eutectic: $1255 \pm 4$} & $\mathrm{~L} \leftrightarrow \operatorname{IrB}_{1.35}+(\mathrm{B})$ & 60 & [23] \\
\hline & $\mathrm{L} \leftrightarrow \mathrm{Ir}_{4} \mathrm{~B}_{5}+(\mathrm{B})$ & & [24] \\
\hline Eutectic: $1240 \pm 8$ & $\mathrm{~L} \leftrightarrow \operatorname{IrB}_{1.5}+(\mathrm{B})$ & $\sim 66$ & [9] \\
\hline Eutectic: 1000 & $\mathrm{L} \leftrightarrow \operatorname{IrB}_{2-x}+(\mathrm{B})$ & $\sim 52$ & [22] \\
\hline
\end{tabular}


which were individually wrapped in tantalum foil and vacuum-sealed in quartz tubes for heat treatments at 800, 900 (1 week) or $1000^{\circ} \mathrm{C}(72 \mathrm{~h})$. Weight losses after melting were insignificant $(<0.5$ mass $\%)$ and no corrections were necessary. For sample characterization, scanning electron microscopy (SEM), electron probe micro-analysis (EPMA), XPD and differential scanning calorimetry (DSC) were used. EPMA composition measurements (in order to determine the proper overall sample composition as well as the individual phase composition) were carried out on a Zeiss Supra 55 VP SEM operated at $20 \mathrm{kV}$ and $60 \mathrm{~mA}$ using WDX analysis. $\mathrm{LaB}_{6}$ and pure iridium served as standards. A Guinier-Huber image plate recording system with monochromatic $\mathrm{Cu}-\mathrm{Ka}_{1}$ radiation provided the XPD data. Lattice parameters were determined with $6 \mathrm{~N}$-germanium as standard. For the Rietveld refinements of the X-ray powder patterns we employed the FULLPROF program [28]. Single crystal X-ray diffraction (XRD) data were collected at room temperature on a Bruker APEXII diffractometer equipped with a CCD (charge coupled device) area detector and an Incoatec Microfocus Source I $\mu \mathrm{S}$ ( $30 \mathrm{~W}$, multilayer mirror, Mo-Ka). Several sets of $\pi$ - and $\omega$-scans with $2.0^{\circ}$ scan width were measured at a crystal-detector distance of $30 \mathrm{~mm}$ up to $\sim 70^{\circ}$ in $2 \theta$ (full sphere). The crystal structures were solved applying direct methods (SHELXS-97 [29]) and refined against $F$ (SHELXL-97-2 [30]) within the program WINGX [31]. The crystal structures were all standardized with the program STRUCTURE TIDY [32]. For melting point measurements, alloy specimens were placed in $\mathrm{BN}$ coated $\mathrm{Al}_{2} \mathrm{O}_{3}$ crucibles in a Netzsch 404 Pegasus DSC equipment and were run under a stream of $6 \mathrm{~N}$ argon and heating rates of $5 \mathrm{~K} / \mathrm{min}$. The equipment was calibrated in the temperature range from 300 to $1400^{\circ} \mathrm{C}$ against pure standard metals supplied by Netzsch to be within $\pm 1^{\circ} \mathrm{C}$. Isothermal reactions and phase boundaries were derived from differential thermal analysis (DTA) heating curves and on alloys that were annealed at subsolidus temperatures prior to the DTA-runs.

\section{Density functional theory (DFT) calculations}

The first-principle calculations were performed within the framework of DFT $[33,34]$ using the Vienna Ab-initio Simulation Package (VASP [35,36] with the projector augmented wave (PAW) method [37]) and the generalized gradient approximation (GGA) within the Perdew-Burke-Ernzerhof (PBE) exchange-correlation functional [38]. The cutoff energy for the expansion of the wave function into plane waves was set at $500 \mathrm{eV}$. All the Brillouin zone integrations were performed on the Monkhorst-Pack $k$-meshes and were sampled with a resolution of $2 \pi \times 0.07 / \AA$, which showed excellent convergence of the energy differences and stress tensors. The enthalpy, density of states and band structures of different phases, were calculated using the tetrahedron method with Blöchl corrections. To check the dynamical stability, we further derived the phonon dispersion curves using the finite-displacement approach as implemented in the Phonopy code [39]. The phonon frequencies are constructed from forces, resulting from displacements of certain atoms in a supercell for each phase.

Our predictions of stable phases with the lowest free energy were carried out using the USPEX code $[40,41]$ in the variable composition mode, which was able to search compositions and structures at the same time. The structures of the first generation were produced randomly and any combination of the numbers of atoms in the unit cell was allowed (within a total number $\leqslant 20$ ). New generations were created through heredity random sampling, lattice mutation and permutation of atoms, with probabilities of $60 \%$, $10 \%, 20 \%$ and $10 \%$, forming the structure pool after discarding the $40 \%$ energetically worst structures. The population size was set to at least twice the number of atoms in the cell. We generally terminated the runs after 50 generations. We then rechecked the stable structures using VASP with much higher precision in order to obtain an accurate result. Moreover, the seed technique was applied during each structural search by adding known structures from experiments or previous search results, in order to enhance the accuracy and efficiency of structure prediction.

\section{RESULTS AND DISCUSSION}

\section{Binary phases in the Ir-B system}

In the binary Ir-B system, four intermediate phases have been reported so far in the literature, namely $\operatorname{Ir}_{4} \mathrm{~B}_{5}$ (earlier labelled as $\operatorname{IrB}_{1.35}$ ), $\operatorname{IrB}_{1.1}$, h- $\operatorname{IrB}_{0.9}$ (high temperature modification) and $\ell-\mathrm{IrB}_{0.9}$ (low temperature modification). Crystallographic data for all phases are summarized in Table 2. A solubility of about 2 at.\% iridium in $\beta$-boron (space group $R \overline{3} m ; a=1.09287(5)$ and $c=2.38274(24)$ $\mathrm{nm})$ has been reported by Crespo et al. [42]. However, a recalculation of the wt.\% Ir in $\beta \mathrm{B}$, as published by Crespo et al., revealed a much smaller solubility of only 0.02 at.\% Ir consistent with the small volume expansion observed [42]. The crystal structures of the binary phases are discussed in detail in the following sections.

\section{The crystal structure of $\operatorname{Ir}_{4} B_{5+x}$ (formerly $\operatorname{IrB}_{1.35}$ )}

A single crystal suitable for X-ray structure analysis was selected from an arc-melted sample with nominal composition $\mathrm{Ir}_{46} \mathrm{~B}_{54}$ (in at.\%) which was crushed in a WC-mortar. 
Table 2 Crystallographic data on the binary Ir-B phases

\begin{tabular}{|c|c|c|c|c|c|c|c|}
\hline \multirow{2}{*}{ Phase } & \multirow{2}{*}{$\begin{array}{l}\text { Space } \\
\text { group }\end{array}$} & \multirow{2}{*}{$\begin{array}{l}\text { Structure } \\
\text { type }\end{array}$} & \multicolumn{3}{|c|}{ Lattice parameter $(\mathrm{nm})$} & \multirow{2}{*}{ Method } & \multirow{2}{*}{ Ref. } \\
\hline & & & $a$ & $b$ & $c$ & & \\
\hline$(\beta B) 1800^{\circ}, 24 \mathrm{~h}$ & $R \overline{3} m$ & $\beta B$ & $1.09276(5)$ & - & $2.38141(15)$ & XPD & {$[42]$} \\
\hline ( $\beta \mathrm{B}) 0.02$ at. $\% \mathrm{Ir}^{\#}$ & $R \overline{3} m$ & $\beta B$ & $1.09287(5)$ & - & $2.38274(24)$ & $\mathrm{XPD}$ & {$[42]$} \\
\hline \multirow[t]{2}{*}{$\mathrm{Ir}_{4} \mathrm{~B}_{5.4}$} & $\mathrm{C} 2 / \mathrm{m}$ & $\mathrm{Ir}_{4} \mathrm{~B}_{5}$ & 1.0525 & $\begin{array}{c}0.2910 \\
\beta=91.07^{\circ}\end{array}$ & 0.6099 & XSCD & {$[13]$} \\
\hline & $\mathrm{C} 2 / \mathrm{m}$ & $\mathrm{Ir}_{4} \mathrm{~B}_{5}$ & $1.052(1)$ & $\begin{array}{c}0.2889(1) \\
\beta=91.09(4)^{\circ}\end{array}$ & $0.6094(7)$ & XPD & $\&$ \\
\hline $\mathrm{Ir}_{4} \mathrm{~B}_{5}$ & $\mathrm{C} 2 / \mathrm{m}$ & $\mathrm{Ir}_{4} \mathrm{~B}_{5}$ & $1.05300(9)$ & $\begin{array}{c}0.29038(3) \\
\beta=91.119(9)^{\circ}\end{array}$ & $0.61013(5)$ & XSCD & $\begin{array}{l}{[14]} \\
\text { Boron rich }\end{array}$ \\
\hline $\mathrm{Ir}_{4} \mathrm{~B}_{5}$ & $\mathrm{C} 2 / \mathrm{m}$ & $\mathrm{Ir}_{4} \mathrm{~B}_{5}$ & $1.0542(1)$ & $\begin{array}{c}0.28905(3) \\
\beta=91.143(6)^{\circ}\end{array}$ & $0.61003(4)$ & XPD & $\begin{array}{l}{[14]} \\
\text { Boron poor }\end{array}$ \\
\hline $\mathrm{Ir}_{4} \mathrm{~B}_{5}$ & $\mathrm{C} 2 / \mathrm{m}$ & $\mathrm{Ir}_{4} \mathrm{~B}_{5}$ & $1.05200(2)$ & $\begin{array}{c}0.289564(6) \\
\beta=91.156(2)^{\circ}\end{array}$ & $0.60958(1)$ & XSCD & * \\
\hline $\operatorname{IrB}_{1.1}$ & $I 4_{1} /$ amd & $\mathrm{ThSi}_{2}$ & 0.2810 & - & 1.0263 & XPD & {$[12]$} \\
\hline $\operatorname{IrB}_{1.1}$ & $I 4_{1} /$ amd & $\mathrm{ThSi}_{2}$ & $\begin{array}{c}0.2808 \\
- \\
0.2811\end{array}$ & - & $\begin{array}{c}1.0259 \\
- \\
1.0248\end{array}$ & $\begin{array}{l}\text { XPD } \\
\text { XPD }\end{array}$ & $\begin{array}{c}\text { for as cast } \operatorname{Ir}_{55} B_{45} \\
\text { for as cast } \operatorname{Ir}_{50} B_{50} \\
\qquad 9]\end{array}$ \\
\hline $\operatorname{IrB}_{1.1}$ & $I 4_{1} /$ amd & $\mathrm{ThSi}_{2}$ & 0.281 & - & 1.026 & XPD & {$[8]$} \\
\hline $\mathrm{Ir}_{5} \mathrm{~B}_{4}$ & $I 4_{1} / a$ & $\mathrm{Ir}_{5} \mathrm{~B}_{4}$ & $0.62777(1)$ & - & $1.02599(2)$ & $\mathrm{XSCD}$ & $*$ \\
\hline $\operatorname{IrB}_{0.9}$ & $\overline{P 6} m 2$ & WC & 0.2815 & - & 0.2823 & $\mathrm{XPD}$ & [16] \\
\hline (hT) & $\overline{P 6} m 2$ & WC & $0.2813(1)$ & - & $0.2826(2)$ & XPD & $\&$ \\
\hline $\operatorname{IrB}_{0.9}(\mathrm{lT})$ & $\mathrm{Cmc2} 2_{1}$ & $\operatorname{IrB}_{0.9}$ & 0.2771 & 0.7578 & 0.7314 & XSCD & {$[16]$} \\
\hline $\mathrm{Ir}_{4} \mathrm{~B}_{3}(\mathrm{lT})$ & $\mathrm{Cmc}_{1}$ & $\mathrm{IrB}_{0.9}$ & $0.27728(1)$ & $0.75742(2)$ & $0.73152(2)$ & XSCD & $*$ \\
\hline (Ir) & $F m \overline{3} m$ & $\mathrm{Cu}$ & 0.38392 & - & - & & {$[47]$} \\
\hline
\end{tabular}

* This work; ${ }^{*}$ calculated from the original data $(0.31$ wt.\% Ir in $(\beta B))$ as published by Crespo et al. [42]; \& evaluated from XPD un-indexed sin ${ }^{2} q$ values published by Brukl and Rudy [9].

Careful inspection of the extinction conditions confirmed the monoclinic symmetry and the structure solution by direct methods was successful in space group $\mathrm{C} 2 / \mathrm{m}$. A first refinement shows consistency with iridium atoms in two $4 i(x, 0, z)$ sites (both on a mirror plane), however, with rather strong anisotropic atom displacement parameters (ADPs). This structure model (see model 1 in Table 3) is essentially consistent with the one earlier described by Aronsson et al. [13]. However, the boron atoms located from our difference Fourier map unambiguously revealed only 3 boron positions (B1, B2, B3) instead of the 4 sites reported by Aronsson et al. [13] of which one (B3) was only half occupied. A difference Fourier map after isotropic refinement of the iridium atoms and subtracting the contribution of the boron atoms, revealed electron density peaks at $\sim 0.1 \AA$ off the mirror plane (see Fig. 1) as previously described by Lundström et al. [14]. Following the arguments by Lundström et al. [14], Ir-atoms were placed in a half filled general position $8 j(x, y, z)$ to satisfy the electron density peaks observed in the difference Fourier map. Re- finement in this case (see model 2 in Table 3) yields rather spherical ADPs for both Ir-atoms and low residual electron densities $<4.88 \mathrm{e} / \AA^{3}$ at $R_{\mathrm{F}}=0.033$. Model 2 in all features confirms the crystal structure reported by Lundström [14]. Fig. 2 shows the unit cell of $\mathrm{Ir}_{4} \mathrm{~B}_{5}$ and the corresponding coordination polyhedra for all atoms. The shortest interatomic bonding distances between the iridium atoms, the iridium and boron atoms and the boron atoms are: $d_{\mathrm{Ir}-\mathrm{Ir}}=0.2660$ $\mathrm{nm}, d_{\mathrm{Ir}-\mathrm{B}}=0.2089 \mathrm{~nm}, d_{\mathrm{B} 1-\mathrm{B} 1}=0.1877 \mathrm{~nm}, d_{\mathrm{B} 1-\mathrm{B} 2}=0.1990 \mathrm{~nm}$, $d_{\mathrm{B} 2-\mathrm{B} 2}=0.2106 \mathrm{~nm}$ and $d_{\mathrm{B} 3-\mathrm{B} 3}=0.1610 \mathrm{~nm}$. These values are in good agreement with those reported earlier [14]. Further details of the crystal structure refinement including interatomic distances for the standardized setting of the structure are summarized in the Supplementary information (Table S1). B1 and B2 atoms form a puckered $2 / \infty$ layer and $\operatorname{Ir}_{4} \mathrm{~B}_{5}$ is thus classified as a structure with a boron net [43]. With only a $50 \%$ occupation of the B3 site, B3 atoms are considered to be isolated in the structure. However, in case of a full occupation of the B3 site, infinite B-B chains would form at a rather short distance $\left(d_{\mathrm{B} 3-\mathrm{B} 3}=0.1610 \mathrm{~nm}\right)$ 
Table 3 Comparison of different structural models for $\operatorname{Ir}_{4} \mathrm{~B}_{5}$ (formerly ' $\operatorname{Ir} \mathrm{B}_{1.35}$ '). The non-standardized setting is kept for an easier comparison with the literature data. Anisotropic displacement parameters $\left(U_{\text {ij }}\right)$ and isotropic temperature factors $U_{\text {iso }}$ and $B_{\text {iso }}\left(=8 \pi^{2} U_{\text {iso }}\right)$ are given in $10^{-2}$ nm ${ }^{2}$

\begin{tabular}{|c|c|c|c|c|}
\hline Compound & $\mathrm{IrB}_{1.35}($ model 1) [13] & $\mathrm{Ir}_{4} \mathrm{~B}_{5}($ model 2) [14] & $\mathrm{Ir}_{4} \mathrm{~B}_{5}($ model 1) this work & $\begin{array}{l}\mathrm{Ir}_{4} \mathrm{~B}_{5} \text { (model 2) this work } \\
\text { (best structure model) }\end{array}$ \\
\hline Space group & $\mathrm{C} 2 / \mathrm{m}$ & $\mathrm{C} 2 / \mathrm{m}$ & $\mathrm{C} 2 / \mathrm{m}$ & $C 2 / m$ \\
\hline $\begin{array}{l}\text { lattice parameter } \\
(\mathrm{nm})\end{array}$ & $\begin{array}{l}a=1.0525, \\
b=0.2910 \\
c=0.6099\end{array}$ & $\begin{array}{l}a=1.05300(9), \\
b=0.29038(3), \\
c=0.61013(5)\end{array}$ & $\begin{array}{c}a=1.05200(2), \\
b=0.289564(6), \\
c=0.60958(1)\end{array}$ & $\begin{array}{c}a=1.05200(2), \\
b=0.289564(6), \\
c=0.60958(1)\end{array}$ \\
\hline$\beta\left(^{\circ}\right)$ & 91.07 & 91.119(9) & $91.156(2)$ & $91.156(2)$ \\
\hline$R$ & 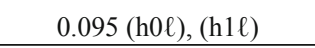 & 0.082 (632 refls) & 0.033 & 0.030 \\
\hline \multicolumn{5}{|l|}{ Atomic parameter } \\
\hline Ir1/Wycoff pos.; & $4 i(0.0994(1), 0,0.1387(2))$ & $\begin{array}{c}8 j \\
(0.09933(9), 0.0310(5) \\
0.1386(1))\end{array}$ & $\begin{array}{c}4 i \\
(0.09936(4), 0 \\
0.13840(7))\end{array}$ & $\begin{array}{c}8 j \\
\left(0.09936(3), 0.0188^{*}\right. \\
0.13838(4))\end{array}$ \\
\hline Occ.; & 1 & 0.5 & $1.001(3)$ & $0.47(5)$ \\
\hline$U_{11}=U_{33}, U_{22} ; B_{\text {iso }}$ & 0.2 & $0.56(2)$ & $0.0014(2), 0.0043(4)$ & $0.0011(1), 0.0012(2)$ \\
\hline Ir2/Wycoff pos.; & $4 i(0.3575(1), 0,0.2885(2))$ & $\begin{array}{c}8 \mathrm{j} \\
(0.35745(9), 0.0292(5) \\
0.2886(1))\end{array}$ & $\begin{array}{c}4 i \\
(0.35747(4), 0 \\
0.28853(7))\end{array}$ & $\begin{array}{c}8 j \\
\left(0.35746(3), 0.0165^{*}\right. \\
0.2883(5))\end{array}$ \\
\hline Occ. & 1 & 0.5 & $0.988(4)$ & $0.48(4)$ \\
\hline$U_{11}=U_{33}, U_{22} ; B_{\text {iso }}$ & 0.2 & $0.59(2)$ & $0.0016(2), 0.0038(2)$ & $0.0011(1), 0.0010(2)$ \\
\hline B1/Wycoff pos.; & $4 i(0.555(4), 0,0.388(6))$ & $4 i(0.554(4), 0,0.381(5))$ & $4 i(0.558(1), 0,0.385(1))$ & $4 i(0.558(1), 0,0.384(1))$ \\
\hline $\begin{array}{l}\text { Occ. } \\
U_{\text {iso }}\end{array}$ & $\begin{array}{c}1 \\
B_{\text {iso }}=0.4\end{array}$ & $\begin{array}{c}1 \\
B_{\text {iso }}=1.3(3)\end{array}$ & $\begin{array}{c}0.99(1) \\
0.004(1)\end{array}$ & $\begin{array}{c}1.0 \\
0.005(2)\end{array}$ \\
\hline B2/Wycoff pos.; & $4 i(0.183(4), 0,0.468(6))$ & $4 i(0.180(2), 0,0.469(3))$ & $4 i(0.178(2), 0,0.462(2))$ & $4 i(0.180(1), 0,0.462(1))$ \\
\hline $\begin{array}{l}\text { Occ. } \\
U_{\text {iso }}\end{array}$ & $\begin{array}{c}1 \\
B_{\text {iso }}=0.5\end{array}$ & $\begin{array}{c}1 \\
B_{\text {iso }}=0.6(2)\end{array}$ & $\begin{array}{c}0.98(7) \\
0.003(1)\end{array}$ & $\begin{array}{c}0.93(5) \\
0.004(2)\end{array}$ \\
\hline B3/Wycoff pos.; & $4 i(0.74(2), 0,0.06(2))$ & $4 i(0.75(1), 0,0.06(1))$ & $4 i(0.739(2), 0,0.053(4))$ & $4 i(0.738(2), 0,0.053(3))$ \\
\hline $\begin{array}{l}\text { Occ. } \\
U_{\text {iso }}\end{array}$ & $\begin{array}{c}0.37 \\
B_{\text {iso }}=2.9\end{array}$ & $\begin{array}{c}0.5(1) \\
B_{\text {iso }}=1.9(9)\end{array}$ & $\begin{array}{c}0.47(4) \\
0.003\end{array}$ & $\begin{array}{c}0.44(3) \\
0.003\end{array}$ \\
\hline B4/Wycoff pos.; & $4 i(0.73(2), 0,0.32(3))$ & - & - & - \\
\hline $\begin{array}{l}\text { Occ. } \\
U_{\text {iso }}\end{array}$ & $\begin{array}{c}0.37 \\
B_{\text {iso }}=2.4\end{array}$ & - & - & - \\
\hline
\end{tabular}

* Fixed before anisotropic refinement of the displacement parameter.
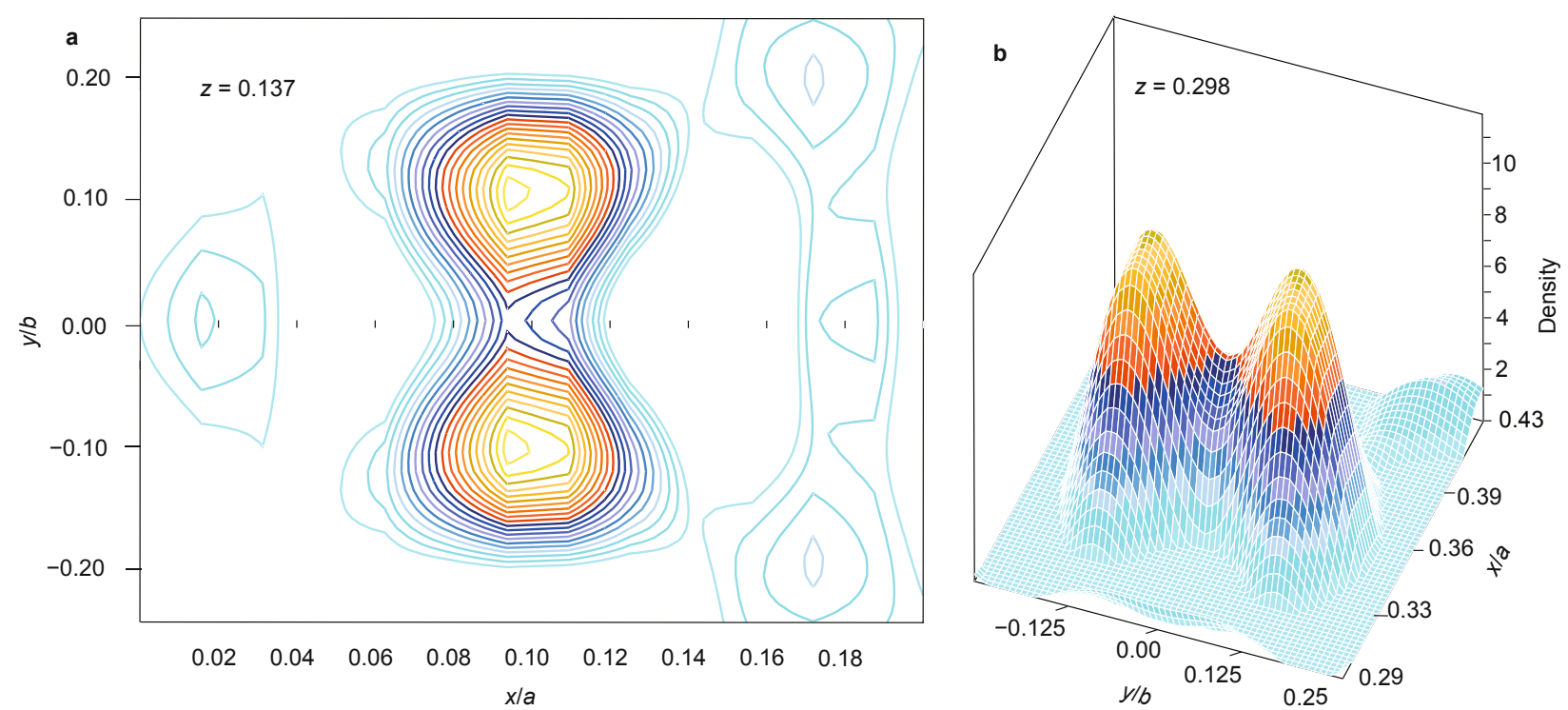

Figure 1 Difference Fourier maps for a) Ir1 and b) Ir 2 after subtracting the contribution of the iridium atoms in the crystallographic sites $4 a$ ( $x, 0, z)$. 


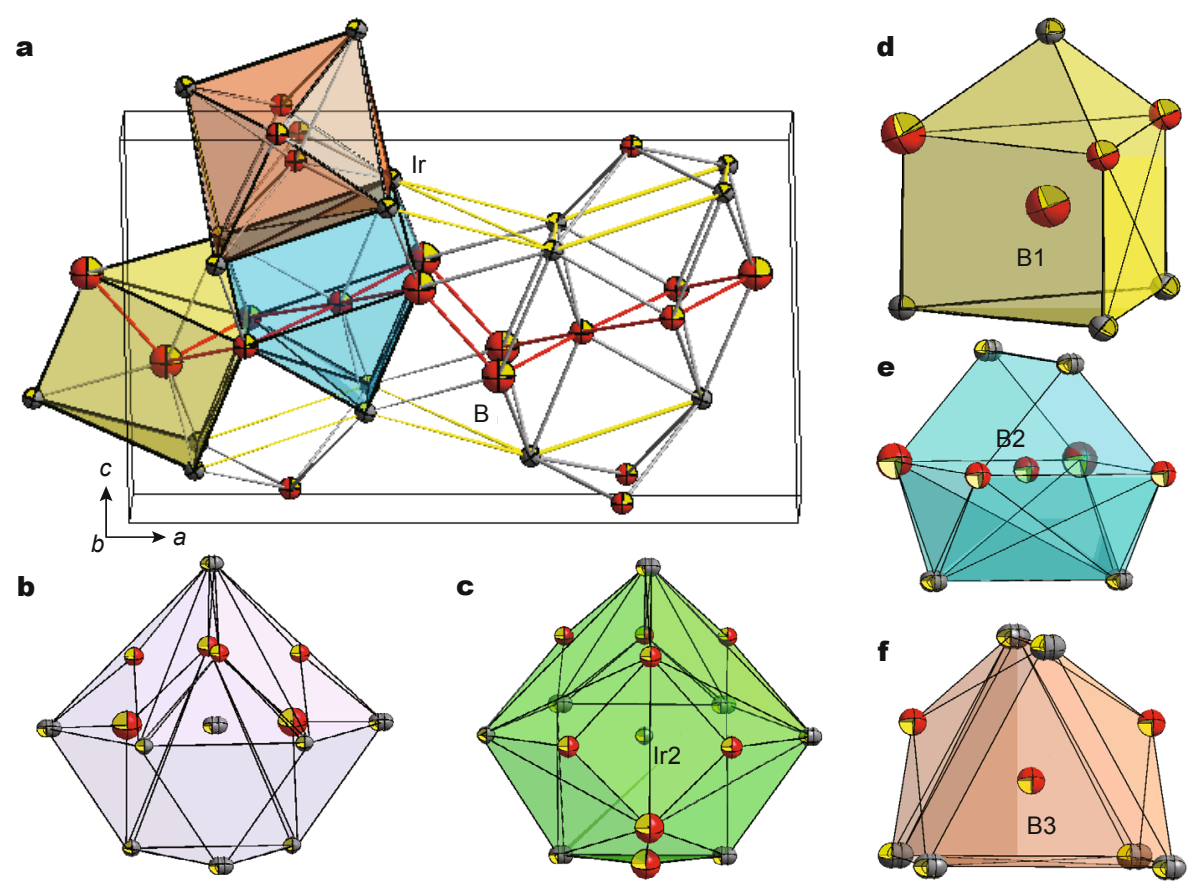

Figure 2 (a) Unit cell of $\operatorname{Ir}_{4} \mathrm{~B}_{5}$ (model 2) and corresponding coordination polyhedra (b) $\operatorname{Ir} 1\left[\mathrm{~B} 1_{2} \mathrm{~B} 2_{1} \mathrm{~B} 3_{3} \operatorname{Ir} 1_{6} \operatorname{Ir} 2_{6}\right]$, (c) $\operatorname{Ir} 2\left[\mathrm{~B} 1_{2} \mathrm{~B} 2_{3} \mathrm{~B} 3_{3} \operatorname{Ir} 1_{10} \mathrm{Ir} 2_{4}\right]$, (d) $\mathrm{B} 1\left[\mathrm{~B} 1_{1} \mathrm{~B} 2_{2} \mathrm{Ir} 1_{4} \mathrm{Ir} 2_{4}\right]$, (e) $\mathrm{B} 2\left[\mathrm{~B} 1_{2} \mathrm{~B} 2_{2} \operatorname{Ir} 1_{2} \operatorname{Ir} 2_{6}\right]$ and (f) $\mathrm{B} 3\left[\mathrm{~B} 3_{2} \mathrm{Ir}_{6} \mathrm{Ir}_{6}\right]$ ). Ir atoms are presented with anisotropic displacement parameters, whereas $\mathrm{B}$ atoms are presented with isotropic ADP's from single crystal refinement.

and further assuming a random (disordered) B3 occupation, chain fragments may exist.

\section{The crystal structure of $\operatorname{Ir}_{5} B_{4+x}$ (formerly $\operatorname{IrB}_{1.1}$ )}

Although our X-ray powder pattern of a single-phase alloy (nominal composition $\operatorname{Ir}_{52} \mathrm{~B}_{48}$ in at.\%) annealed at $900^{\circ} \mathrm{C}$ could be indexed on the basis of the $\alpha-\mathrm{ThSi}_{2}$ structure type (see Fig. 3) as published for the compound labelled in the literature as ' $\mathrm{IrB}_{1.1}$ ' (space group $\mathrm{I}_{1} /$ amd; $a=0.281$ and $c$ $=1.026 \mathrm{~nm}$ [12]), the calculated intensities from Rietveld refinement did not fit well with the experimental observation. Therefore, a structure analysis has been attempted on a single crystal specimen mechanically isolated from the sample with nominal composition $\operatorname{Ir}_{53} B_{47}$ (in at.\%) obtained after the DSC measurement. Diffraction data for this crystal confirmed the tetragonal symmetry but revealed a 5 times larger unit cell $\left(a=\sqrt{5} a_{\mathrm{ThSi}_{2}}=0.62777(1)\right.$ and $\left.c=c_{\mathrm{ThSi}_{2}}=1.02599(2) \mathrm{nm}\right)$ compared with the $\alpha-\mathrm{ThSi}_{2}$ type. The analysis of the systematic extinctions arrived at the space group $I 4_{1} / a$ as the one with the highest symmetry. The corresponding refinement prompted iridium atoms in the crystallographic site $4 a(0,1 / 4,1 / 8)$ and in the general position $16 f(0.10581(4), 0.04891(3), 0.37895(3))$. After subtracting the contribution of the iridium atoms, the difference Fourier map contained only one set of electron density peaks, which could correspond to boron atoms (in $16 f(0.2876(8), 0.1578(8), 0.0339(6)))$. A final refinement with anisotropic atom displacement parameters (ADPs) for the iridium atoms but isotropic temperature factors for the boron atoms revealed rather spherical shapes for both $\mathrm{Ir}$ atoms and converged to a low $R$-value of $R_{\mathrm{F}}=0.031$ and residual electron densities smaller than $\pm 4.5 \AA^{3}$. Occupancies were refined for all atoms, but within a standard deviation of $2 s$ indicated no deviation from a full occupation. Results of the refinement are summarized in Table 4 and describe a completely ordered atom arrangement with the structure formula $\operatorname{Ir}_{5} \mathrm{~B}_{4}$. A 3-dimensional view of the unit cell is presented in Fig. $4 \mathrm{a}$. Figs $4 \mathrm{~b}-\mathrm{d}$ show the corresponding coordination polyhedra for all atoms. The shortest interatomic bonding distances, $d_{\mathrm{Ir}-\mathrm{Ir}}=0.2778 \mathrm{~nm}$ and $d_{\mathrm{Ir}-\mathrm{B}}=0.2114 \mathrm{~nm}$, are consistent with the sum of atom radii and a strong $\mathrm{Ir}-\mathrm{B}$ bond (for atom radii, see [44]). Although the parent $\mathrm{ThSi}_{2}$-type exhibits a 3-dimensionally linked Si-framework (see Fig. 4), no direct B-B bonds are present in $\operatorname{Ir}_{5} \mathrm{~B}_{4}\left(d_{\mathrm{B}-\mathrm{B}}=0.2906 \mathrm{~nm}\right)$. Following the structural-chemical classification of borides as a function of $\mathrm{B}-\mathrm{B}$ aggregation [43], the structure of $\operatorname{Ir}_{5} \mathrm{~B}_{4}$ is classified as a new structure with isolated boron atoms in trigonal prismatic metal environment (Fig. 4d). The crystal structure can be conceived as a new and ordered derivative of the $\alpha-\mathrm{ThSi}_{2}$ 


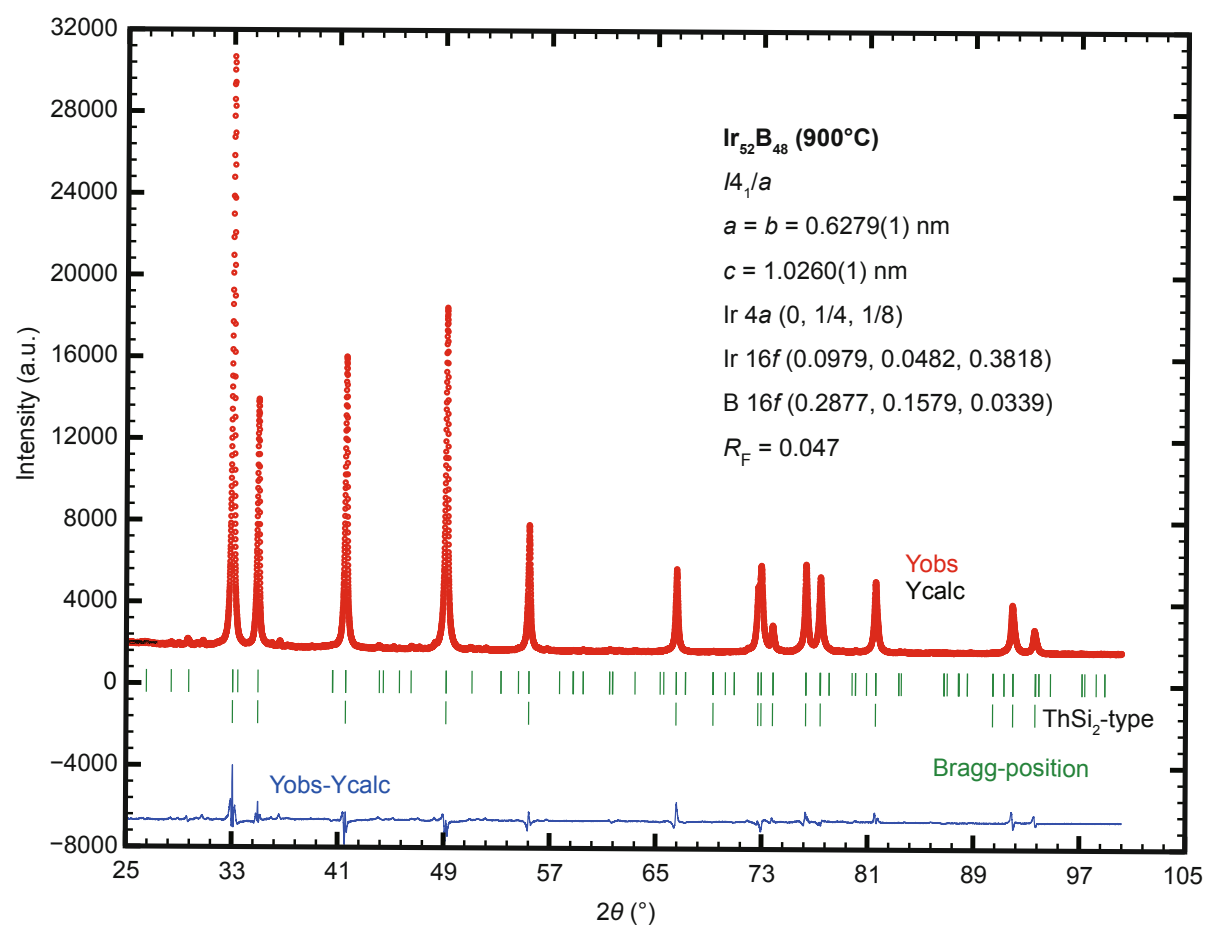

Figure 3 Rietveld refinement for an alloy with nominal composition $\operatorname{Ir}_{52} \mathrm{~B}_{48}$ annealed at $900^{\circ} \mathrm{C}$ applying the $\operatorname{Ir}_{5} \mathrm{~B}_{4}$ structure type and Bragg positions for the $\mathrm{ThSi}_{2}$ structure type.

type. The corresponding crystallographic group-subgroup scheme in form of a Bärnighausen tree [45] is shown in Fig. 5 and compares the unit cells of the $\alpha-\mathrm{ThSi}_{2}$ type (Fig. 5a) and $\operatorname{Ir}_{5} B_{4}$ (Fig. 5b). As can be seen at the bottom of the scheme, the Wyckoff positions $16 f$ and $8 e$ (parent B-sites) are not occupied in the $\operatorname{Ir}_{5} \mathrm{~B}_{4}$ structure type. Therefore, one can assume that boron-vacancy ordering leads to the formation of this new structure type. A Rietveld refinement of the X-ray powder pattern with the new structure type is shown in Fig. 3. It should be noted here that the intensities of the superstructure reflections are rather small and almost indistinguishable from the background. In order to rule out the existence of a disordered and defect $\alpha-\mathrm{ThSi}_{2}$ structure type (as reported earlier $[8,12]$ ) in the phase diagram, further single crystals were investigated, which were isolated from two alloys, one located close to the B-poor and the second one located close to the B-rich flanks of the $\operatorname{Ir}_{5} \mathrm{~B}_{4}$ phase, respectively. The locations of these alloys were carefully checked by DTA yielding small signals of the relevant isothermal reactions of the adjoining phases. Diffraction spectra of all crystals requested indexation on a tetragonal lattice with $a=\sqrt{5} a_{\mathrm{ThSi}_{2}}, c=c_{\mathrm{ThS}_{2}}$ confirming the superstructure. Due to the low intensity superstructure reflections, earlier investigations based on X-ray film techniques were likely not aware of them describing the crys- tal structure of $\operatorname{Ir}_{5} \mathrm{~B}_{4+x}$ (formerly $\operatorname{IrB}_{1.1}$ ) with a simple disordered and defect $\alpha-\mathrm{ThSi}_{2}$ type. Our investigation clearly documents boron/vacancy ordering in a five times larger unit cell.

\section{High and low temperature modifications of $\operatorname{Ir}_{4} B_{3-x}$ (formerly $\operatorname{IrB}_{0.9}$ )}

Rogl et al. [16] reported for $\operatorname{IrB}_{0.9}$ a high temperature (hT) modification with WC-type (space group $P \overline{6} m 2 ; a=0.2815$ and $c=0.2823 \mathrm{~nm}$ ) and a low temperature ( $\ell T)$ modification (own type; space group $C m c 2_{1} ; a=0.2771, b=0.7578$ and $c=0.7314 \mathrm{~nm}$ ). A reversible transformation from single phase low temperature material (alloy $\operatorname{Ir}_{55} \mathrm{~B}_{45}$ (in at.\% B) obtained at $1100^{\circ} \mathrm{C}$ ) into a practically single phase high temperature modification was observed, when heated to $\sim 1200^{\circ} \mathrm{C}$ : high and low temperature phases were simultaneously present at temperatures of 1100 to $1200^{\circ} \mathrm{C}$, but transformed to a single low temperature phase after anneal of $12 \mathrm{~h}$ at $800^{\circ} \mathrm{C}$ [16]. The $\ell T$ modification has been assigned from single crystal X-ray Weissenberg multiple film data whereas the $\mathrm{h} T$ modification from XPD photographs. In the WC structure type, the Ir atoms occupy the crystallographic site $1 a(0,0,0)$ and the boron atoms occupy the site $1 d(1 / 3,2 / 3,1 / 2)$, which is only partially filled. Reinvestigations of this phase by XPD and EPMA confirm the 
Table 4 X-ray single crystal data for $\operatorname{Ir}_{5} \mathrm{~B}_{4}$ at RT standardized with the program STRUCTURE TIDY (Mo Ka-radiation; $2^{\circ} \leqslant 2 q \leqslant 70^{\circ} ; \omega$-scans, scan width $2^{\circ} ; 150 \mathrm{sec} /$ frame; anisotropic displacement parameters $U_{\mathrm{ij}}$ in $\left.\left(10^{-2} \mathrm{~nm}^{2}\right)\right)$

\begin{tabular}{|c|c|c|c|c|}
\hline \multicolumn{2}{|c|}{ Parameter/compound } & \multicolumn{3}{|c|}{$\mathrm{Ir}_{5} \mathrm{~B}_{4}$} \\
\hline \multicolumn{2}{|c|}{ Space group } & \multicolumn{3}{|c|}{$I 4_{1} / a$} \\
\hline \multicolumn{2}{|c|}{ Formula from EPMA } & \multicolumn{3}{|c|}{$\mathrm{Ir}_{5} \mathrm{~B}_{4.2}$} \\
\hline \multicolumn{2}{|c|}{ Formula from refinement } & \multicolumn{3}{|c|}{$\mathrm{Ir}_{5} \mathrm{~B}_{4}$} \\
\hline \multicolumn{2}{|c|}{$a, c[\mathrm{~nm}]$} & \multicolumn{3}{|c|}{$0.62777(1), 1.02599(2)$} \\
\hline \multicolumn{2}{|c|}{$m_{\mathrm{abs}}(/ \mathrm{mm})$} & \multicolumn{3}{|c|}{32.8} \\
\hline \multicolumn{2}{|c|}{$V\left(\mathrm{~nm}^{3}\right)$} & \multicolumn{3}{|c|}{0.40434} \\
\hline \multicolumn{2}{|l|}{$\rho_{x}\left(\mathrm{~g} \mathrm{~cm}^{-3}\right)$} & \multicolumn{3}{|c|}{16.5} \\
\hline \multicolumn{2}{|c|}{ Reflections in refinement } & \multicolumn{3}{|c|}{$426^{3} 4 s \sigma\left(F_{\mathrm{o}}\right)$ of 495} \\
\hline \multicolumn{2}{|c|}{ Number of variables } & \multicolumn{3}{|c|}{19} \\
\hline \multicolumn{2}{|c|}{$R_{\mathrm{F}}=\Sigma\left|F_{0}-F_{\mathrm{c}}\right| / \Sigma F_{0}$} & \multicolumn{3}{|c|}{0.031} \\
\hline \multicolumn{2}{|c|}{$R_{\text {Int }}$} & \multicolumn{3}{|c|}{0.067} \\
\hline \multicolumn{2}{|l|}{$\mathrm{w} R 2$} & \multicolumn{3}{|c|}{0.10} \\
\hline \multicolumn{2}{|l|}{ GOF } & \multicolumn{3}{|c|}{1.090} \\
\hline Extinction (Zach & asen) & & 0.0038 & \\
\hline Residual density $\left(\mathrm{e} / \AA^{3}\right)$ & ax; $\min$ & & $3.03 ;-4$ & \\
\hline Atom parameters & & & & \\
\hline Ir 1 in $16 f(x, y, z$ & cc. & & 0.99( & \\
\hline$x, y, z$ & & 0.1058 & 4), 0.04891 & $0.37895(3)$ \\
\hline$U_{11}=U_{22}, U$ & & & $0031(2), 0$ & $8(3)$ \\
\hline Ir2 in $4 a(0,1 / 4,1 / 8$ & occ. & & 0.99 & \\
\hline$U_{11}=U_{33}, L$ & & & $0027(2), 0$ & $9(2)$ \\
\hline B1 in $16 f(x, y, z$ & & & 0.99 & \\
\hline$x, y, z$ & & 0.287 & (8), 0.1578 & $0.0339(6)$ \\
\hline$U_{\text {iso }}$ & & & 0.0061 & \\
\hline Interatomic distances ( & ); standa & deviati & $n<0.0001$ & \\
\hline $\operatorname{Ir} 1-$ & 0.2152 & Ir2 - & $4 \mathrm{~B} 1$ & 0.2114 \\
\hline$-1 \mathrm{~B} 1$ & 0.2153 & & $-4 \operatorname{Ir} 1$ & 0.2778 \\
\hline$-1 \mathrm{~B} 1$ & 0.2160 & & $-4 \operatorname{Ir} 1$ & 0.2970 \\
\hline$-1 \mathrm{~B} 1$ & 0.2201 & $\mathrm{~B} 1-$ & $1 \mathrm{Ir} 2$ & 0.2114 \\
\hline$-1 \mathrm{~B} 1$ & 0.2292 & & $-1 \operatorname{Ir} 1$ & 0.2152 \\
\hline$-1 \operatorname{Ir} 2$ & 0.2778 & & $-1 \operatorname{Ir} 1$ & 0.2153 \\
\hline$-2 \operatorname{Ir} 1$ & 0.2816 & & $-1 \operatorname{Ir} 1$ & 0.2160 \\
\hline$-1 \mathrm{Ir} 1$ & 0.2853 & & $-1 \operatorname{Ir} 1$ & 0.2201 \\
\hline$-1 \mathrm{Ir} 1$ & 0.2883 & & $-1 \operatorname{Ir} 1$ & 0.2906 \\
\hline$-2 \operatorname{Ir} 1$ & 0.2899 & & $-1 \mathrm{~B} 1$ & $(0.2906)$ \\
\hline$-1 \mathrm{Ir} 2$ & 0.2970 & & & \\
\hline
\end{tabular}

small hexagonal unit cell but with a slightly lower boron content (EPMA; $\operatorname{IrB}_{0.7-0.75} \equiv \operatorname{IrB}_{1-x} ; a=0.28132(2)$ and $c=$ $0.28298(2) \mathrm{nm})$. Although the precise boron site occupancy has not been determined yet, the formula suggests a defect WC-type. Crystallographic WC-type derives from the $\mathrm{AlB}_{2}$-type when only every second trigonal metal prism is occupied by a $\mathrm{C}$ atom. In the $\mathrm{AlB}_{2}$ structure type, rather
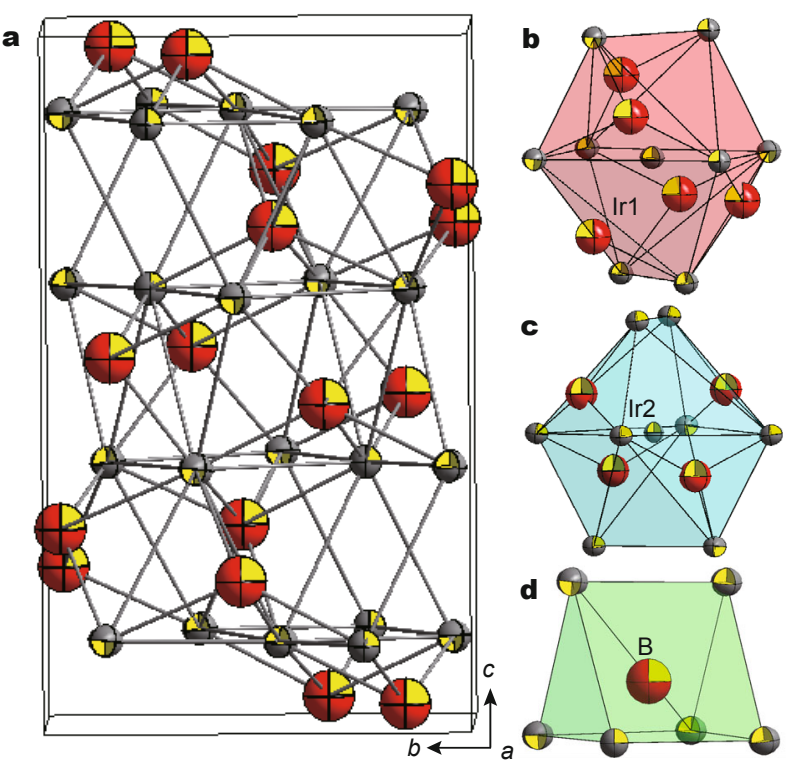

Figure 4 Crystal structure of $\operatorname{Ir}_{5} \mathrm{~B}_{4}$ (a) 3-dim view of the unit cell, coordination figures, (b) $\operatorname{Ir} 1\left[\mathrm{~B}_{5} \operatorname{Ir} 1_{6} \operatorname{Ir} 2_{2}\right]$, (c) $\operatorname{Ir} 2\left[\mathrm{~B}_{4} \operatorname{Ir} 1_{8}\right]$, (d) $\mathrm{B}\left[\operatorname{Ir} 1_{5} \operatorname{Ir} 2_{1}\right]$. Ir atoms are presented with anisotropic displacement parameters, whereas B-atoms are presented with isotropic ADP's from single crystal refinement.

short B-B distances $\left(d_{\mathrm{B}-\mathrm{B}}=0.1624 \mathrm{~nm}\right)$ would arise from a random distribution of the $\mathrm{B}$ atoms over the 2 fold site (Ir in $1 a(0,0,0)$ and $\mathrm{B}$ in $2 d(1 / 3,2 / 3,1 / 2))$, which is rather unlikely for low boron metal borides (see also $[16,43]$ ).

For a new evaluation of the crystal structure of the low temperature phase, a single crystal specimen was mechanically isolated from the sample with nominal composition $\operatorname{Ir}_{60} B_{40}$, which was slowly cooled in a DSC experiment. Analysis of the XRD spots confirmed the previously reported orthorhombic C-centered unit cell ( $a=0.27728(1)$, $b=0.75742(2)$ and $c=0.73152(2) \mathrm{nm}$ ) and the observed extinctions led to the possible space groups $\mathrm{Cmcm}, \mathrm{C} 2 \mathrm{~cm}$ (standardized setting Ama2) and $C m c 2_{1}$. Placing the iridium atoms in the crystallographic sites $4 a(0,0,0)$ and $4 c$ $(0, y, 1 / 4)$ in the highest symmetric centrosymmetric space group $\mathrm{Cmcm}$ results immediately in an $R_{\mathrm{F}}$ value lower than $4 \%$. A difference Fourier analysis showed two possible crystallographic sites for the boron atoms (B1 in $4 c$ and B2 in $8 f(0, y, z))$, however, with only partial filling in both sites (occ. $(\mathrm{B} 1)=0.80(6)$ and occ. $(\mathrm{B} 2)=0.32(7))$. The highest residual electron density $\left(8.9 \mathrm{e} / \AA^{3}\right)$ is too close to Ir 1 $(0.139 \mathrm{~nm})$ for another boron atom. The shortest interatomic distances are: $d_{\mathrm{Ir}-\mathrm{Ir}}=0.2771, d_{\mathrm{Ir}-\mathrm{B}}=0.2057$ and $d_{\mathrm{B} 2-\mathrm{B} 2}=$ $0.1751 \mathrm{~nm}$. The Ir-B distances are slightly smaller than the sum of the atomic radii as an indication of strong bonding. Smaller values are not exceptional for platinum metal borides, especially as both boron sites are only partially filled. 

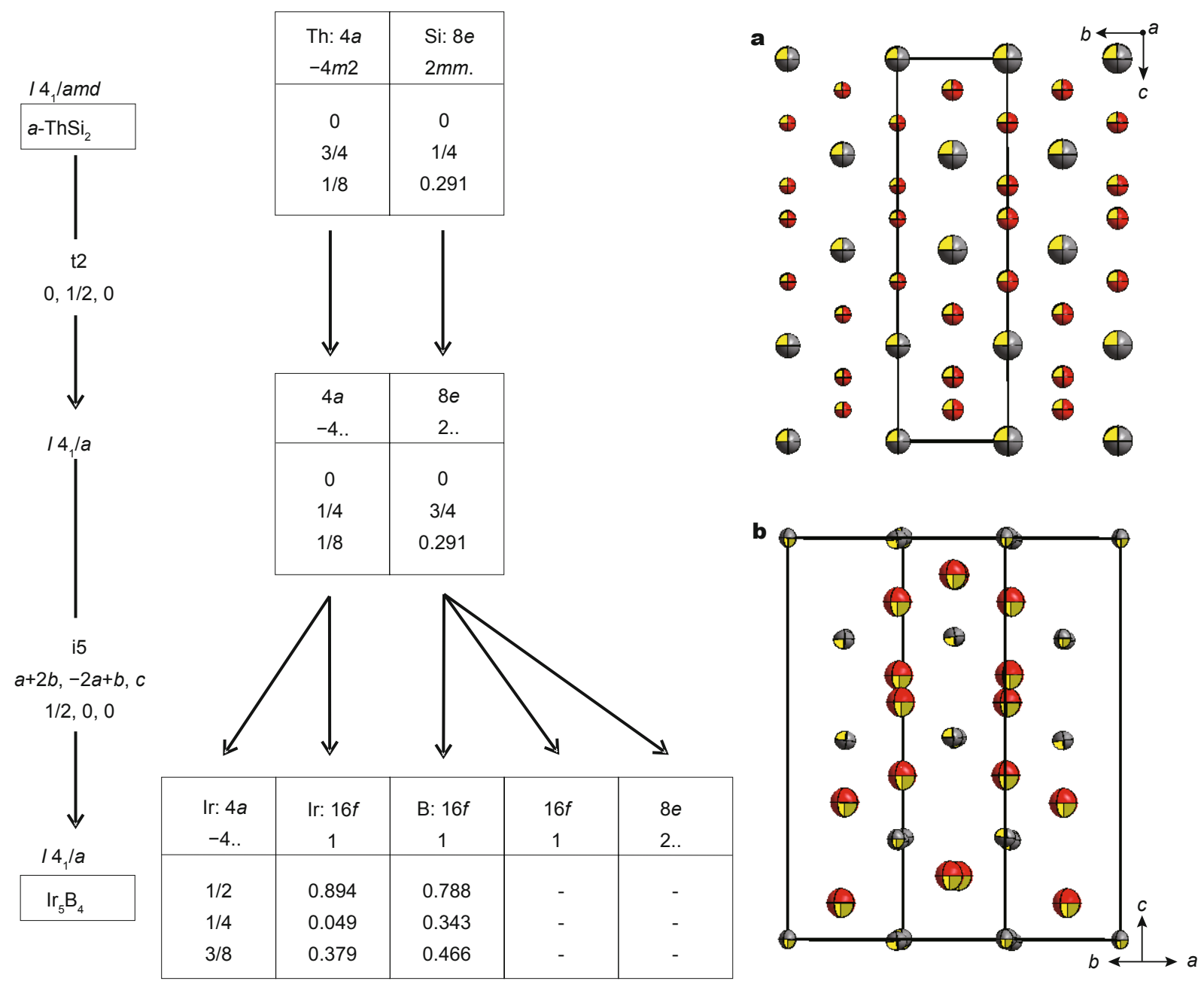

Figure 5 Group-subgroup relations in form of a Bärnighausen tree for the pair of structures: $\alpha-\operatorname{ThSi}_{2}-\mathrm{Ir}_{5} \mathrm{~B}_{4}$; the unit cells of (a) $\alpha-\mathrm{ThSi}_{2}$ and (b) $\mathrm{Ir}_{5} \mathrm{~B}_{4}$ (origin has been shifted for both compounds) are shown for comparison.

The boron-boron aggregation in this space group reveals isolated atoms B1 $\left(d_{\mathrm{B} 1-\mathrm{B} 2}=0.2254 \mathrm{~nm}\right)$ but atoms B2 form boron zigzag chains along the $a$ axis at an unlikely low occupancy of the B2-site (occ. $(B 2)=0.32(7)$ ). Therefore in search for B-sites of lower multiplicity, alternative refinements were performed in the lower symmetry non-centrosymmetric space groups $\mathrm{C} 2 \mathrm{~cm}$ and $C m c 2_{1}$. Through the standardization process from the non-standard setting $C 2 \mathrm{~cm}$ to the standard setting Ama2, the axes have been changed to $c,-b, a$ and also the atomic coordinates (see Table 5), however, symmetry did not allow boron ordering i.e., a separation of the 8-fold B2-site into two 4-fold sites. Therefore the refinement leads to a similar atom arrangement with practically identical $R$ values, occupancies and interatomic distances.

Refinement in the non-centrosymmetric space group
$C m c 2_{1}$ finally offers a reduction of the multiplicity of the B2-site (4a) yielding full occupancy for the metal atom sites in $4 a(0, y, z)$, but also about 75 to $80 \%$ for both boron atoms in sites $4 a$ (occ.(B1) $=0.71(8)$ and occ.(B2) $=$ $0.79(9))$. Interatomic distances $\left(d_{\mathrm{Ir}-\mathrm{B}}=0.2119\right.$ and $d_{\mathrm{B} 1-\mathrm{B} 2}$ $=0.1988 \mathrm{~nm}$ ) are within the sum of the atomic radii. Final refinement with ADPs for iridium but isotropic thermal parameters for the light boron atoms in all 3 cases converged to $R$-values between 0.032 and $0.038\left(R_{\mathrm{F}(\mathrm{Cmcm})}\right.$ $\left.=0.038, R_{\mathrm{F}(\mathrm{Ama} 2)}=0.032, R_{\mathrm{F}\left(\mathrm{Cmc2_{1 } )}\right.}=0.035\right)$. The atom site distributions in the unit cells of $\operatorname{Ir}_{4} \mathrm{~B}_{3}$, as refined in the different space groups, are shown at the bottom of Table 5. A comparison of the crystal structure data of $\operatorname{Ir}_{4} \mathrm{~B}_{3}$ for all the three space group types is given in Table 5. Considering fully occupied boron sites, boron chains are present in the first two, whereas only boron pairs $\left(d_{\mathrm{B} 1-\mathrm{B} 2}=0.1988 \mathrm{~nm}\right)$ are 
Table 5 Comparison of the crystal structure refinements for $\operatorname{Ir}_{4} \mathrm{~B}_{3-x}$ in the 3 possible space groups $\mathrm{Cmcm}$ (the non-standard setting is used for an easier comparison), $C 2 \mathrm{~cm}$ (standardized setting Ama2) and $\mathrm{Cmc} 2_{1}$

\begin{tabular}{|c|c|c|c|}
\hline Composition from refinement & $\mathrm{Ir}_{4} \mathrm{~B}_{2.9}$ & $\mathrm{Ir}_{4} \mathrm{~B}_{3}$ & $\mathrm{Ir}_{4} \mathrm{~B}_{3}$ (best structure) \\
\hline Space group & $\mathrm{Cmcm}(63)$ & $\operatorname{Ama2}(40)$ & $\mathrm{Cmc2}_{1}(36)$ \\
\hline \multirow[t]{3}{*}{ Lattice parameter (nm) } & $a=0.27728(1)$ & $a=0.73152(2)$ & $a=0.27728(1)$ \\
\hline & $b=0.75742(2)$ & $b=0.75742(2)$ & $b=0.75742(2)$ \\
\hline & $c=0.73152(2)$ & $c=0.27728(1)$ & $c=0.73152(2)$ \\
\hline$R_{\mathrm{F}}=\Sigma\left|F_{0}-F_{\mathrm{C}}\right| / \Sigma F_{0}$ & 0.038 & 0.032 & 0.034 \\
\hline Number of variables & 8 & 20 & 16 \\
\hline Residual density $\left(\mathrm{e} / \AA^{3}\right)$ : $\max$; min & $8.93,-7.9$ & $8.88,-7.67$ & $8.27,-6.25$ \\
\hline Reflections in refinement & $217 \geqslant 4 \sigma\left(F_{\mathrm{o}}\right)$ of 231 & $342 \geqslant 4 \sigma\left(F_{\mathrm{o}}\right)$ of 361 & $371 \geqslant 4 \sigma\left(F_{\mathrm{o}}\right)$ of 394 \\
\hline
\end{tabular}

Atomic parameter

\section{Ir1/Wycoff pos.;}

Occ.; $U_{11}, U_{22}, U_{33}$

Ir2/Wycoff pos.;

Occ.; $U_{11}, U_{22}, U_{33 /}$

B1/Wycoff pos.;

Occ.; $U_{11}, U_{22}, U_{33}$

B2/Wycoff pos.;

Occ.; $U_{11}, U_{22}, U_{33}$

$4 a(0,0,0) ;$
$1 ; 0.0004(3), 0.0001(4), 0.0013(4)$
$4 c(0,0.27591(7), 1 / 4) ;$
$1 ; 0.0007(4), 0.0010(4), 0.0009(4)$
$4 c(1 / 2,0.064(2), 1 / 4) ;$
$0.80(6) ; 0.003(3)$
$8 f(1 / 2,0.204(5), 0.055(4)) ;$
$0.32(7) ; 0.004(6)$

$4 a(0,0,0)$;

$1 ; 0.0004(3), 0.0001(4), 0.0013(4)$

$1 ; 0.0007(4), 0.0010(4), 0.0009(4)$

$8 f(1 / 2,0.204(5), 0.05$
$0.32(7) ; 0.004(6)$

Shortest distances (nm)

$d_{\mathrm{Ir}-\mathrm{Ir}} ; d_{\mathrm{Ir}-\mathrm{B}} ; d_{\mathrm{B}-\mathrm{B}}$

$0.2771 ; 0.2057 ; 0.1751$

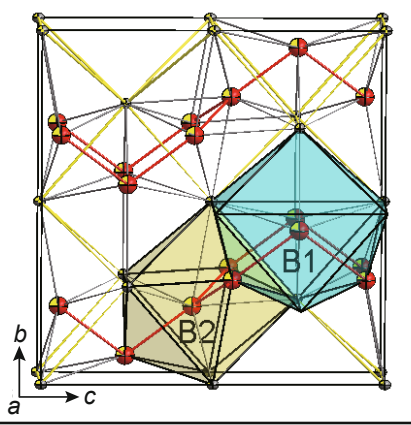

\section{Unit Cell}

(yellow: Ir-Ir bonds; red: $\mathrm{B}-\mathrm{B}$ bonds and grey: $\mathrm{Ir}-\mathrm{B}$ bond)
$4 a(0,0,0 *)$;

$1 ; 0.0012(4), 0.0001(3), 0.0009(4)$

$4 b(1 / 4,0.27602(7), 0.003(1))$;

1; 0.0009(4); 0.0009(4), 0.0003(4)

$4 b(1 / 4,0.065(2), 0.475(1))$;

$0.82(4) ; 0.004(1)$

$8 c(0.051(4), 0.205(4)$,

$0.513(6)) ; 0.35(4) ; 0.004(2)$
$4 a(0,0.0015(2), 0.051(1))$;

$1 ; 0.0001(3), 0.0001(3), 0.0010(3)$

$4 a(0,0.27600(9), 0.302(1))$;

$1 ; 0.0003(2), 0.0006(3), 0.0009(3)$

$4 a(0,0.289(1), 0.0004(3))$;

$0.71(8) ; 0.002(7)$

$4 a(0,0.559(1), 0.306(1))$

$0.79(9) ; 0.005(3)$
$0.2772 ; 0.2080 ; 0.1689$

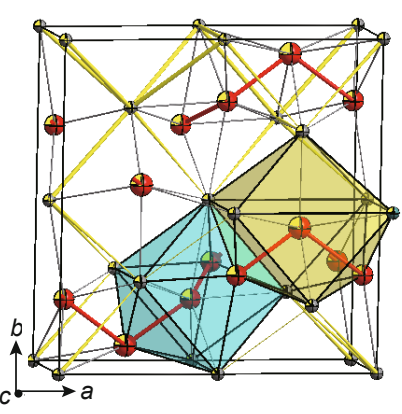

$0.2761 ; 0.2119 ; 0.1988$

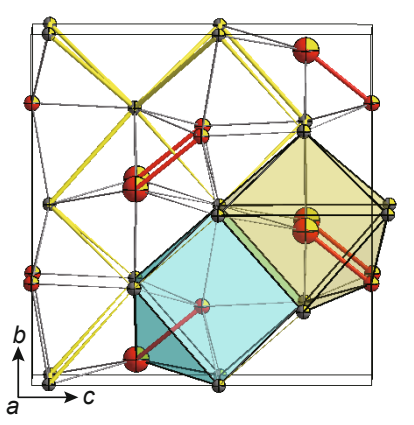

* Fixed during refinement.

present after refinement in $\mathrm{Cmc2}_{1}$. The complete results of the crystal structure refinement in this space group can be found in the Supplementary information (Table S2). The unit cell with the corresponding coordination polyhedra is shown in Fig. 6. The finally refined composition of this crystal is $\operatorname{Ir}_{4} \mathrm{~B}_{3}$, which is in good agreement with the result from EPMA measurement $\left(\operatorname{Ir}_{4} \mathrm{~B}_{2.8}\right)$. As has been mentioned previously [16], neutron diffraction studies and DFT calculations would be helpful for a final decision about the exact atom distribution in the boron sublattices. It should be mentioned here, that our DFT calculations (see below) revealed that the $C m c 2_{1}$ phase holds the lowest formation energy compared to the other two structure models $(\mathrm{Cmcm}$ and Ama2).

\section{The phase diagram for the Ir-B system}

Phase formation/decomposition and isothermal reactions
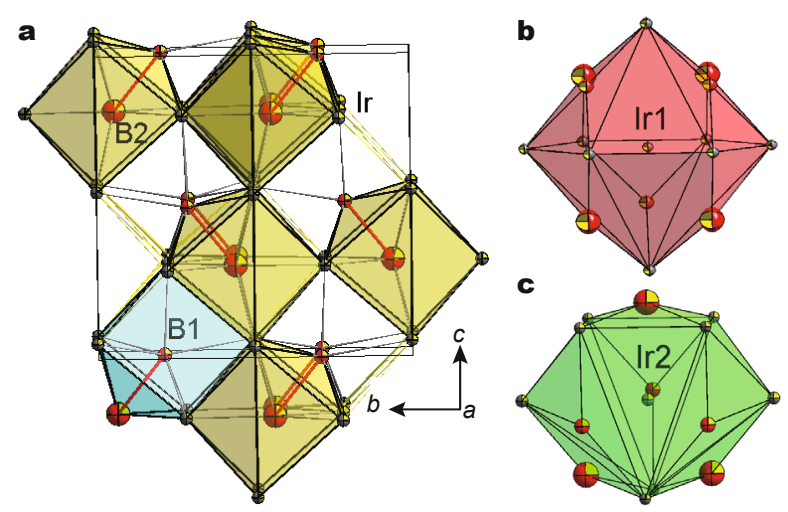

Figure 6 Crystal structure of $\operatorname{Ir}_{4} \mathrm{~B}_{3}$ (a) unit cell including coordination polyhedra around the boron atoms $\left(\mathrm{B} 1\left[\mathrm{~B} 2_{1} \operatorname{Ir} 1_{3} \operatorname{Ir} 2_{3}\right], \mathrm{B} 2\left[\mathrm{~B} 1_{1} \operatorname{Ir} 1_{4} \operatorname{Ir} 2_{3}\right]\right)$ and coordination polyhedra for the iridium atoms (b) $\operatorname{Ir} 1\left[\mathrm{~B} 1_{3} \mathrm{~B} 2_{4} \operatorname{Ir} 1_{2} \operatorname{Ir} 2_{6}\right]$ and (c) $\operatorname{Ir} 2\left[\mathrm{~B} 1_{3} \mathrm{~B} 2_{3} \operatorname{Ir} 1_{6} \operatorname{Ir} 2_{2}\right]$. Ir atoms are presented with anisotropic displacement parameters, whereas B atoms are presented with isotropic ADPs from single crystal refinement. 
in the binary system Ir-B have been studied on about 50 samples in the composition range between 20 and 90 at.\% boron by XPD, EPMA and DSC. Whereas the crystal structures of the binary compounds were determined from $\mathrm{X}$-ray single crystals, phase relations were derived by XPD, metallography and DTA on annealed alloys. For liquidus and solidus curves we relied on DTA heating curves on annealed alloys. The microstructures with phase analyses by EPMA served to confirm or establish isothermal reaction types, location of peritectic and eutectic points as well as the extent of phase homogeneity regions. The microstructures of several selected alloys in as cast state are shown in Fig. 7 and the corresponding results from EPMA and XPD are summarized in Table 6. The microstructure of an alloy with nominal composition $\operatorname{Ir}_{42} \mathrm{~B}_{58}$ (Fig. 7a) shows primary crystallization of $\operatorname{Ir}_{4} \mathrm{~B}_{5+x}$ followed by the crystallization of a boron rich eutectic $\mathrm{e}_{1}: \mathrm{L} \leftrightarrow \beta \mathrm{B}+\mathrm{Ir}_{4} \mathrm{~B}_{5+x}$ at $1256 \pm 6^{\circ} \mathrm{C}$. The invariant reaction temperature corresponds well with those
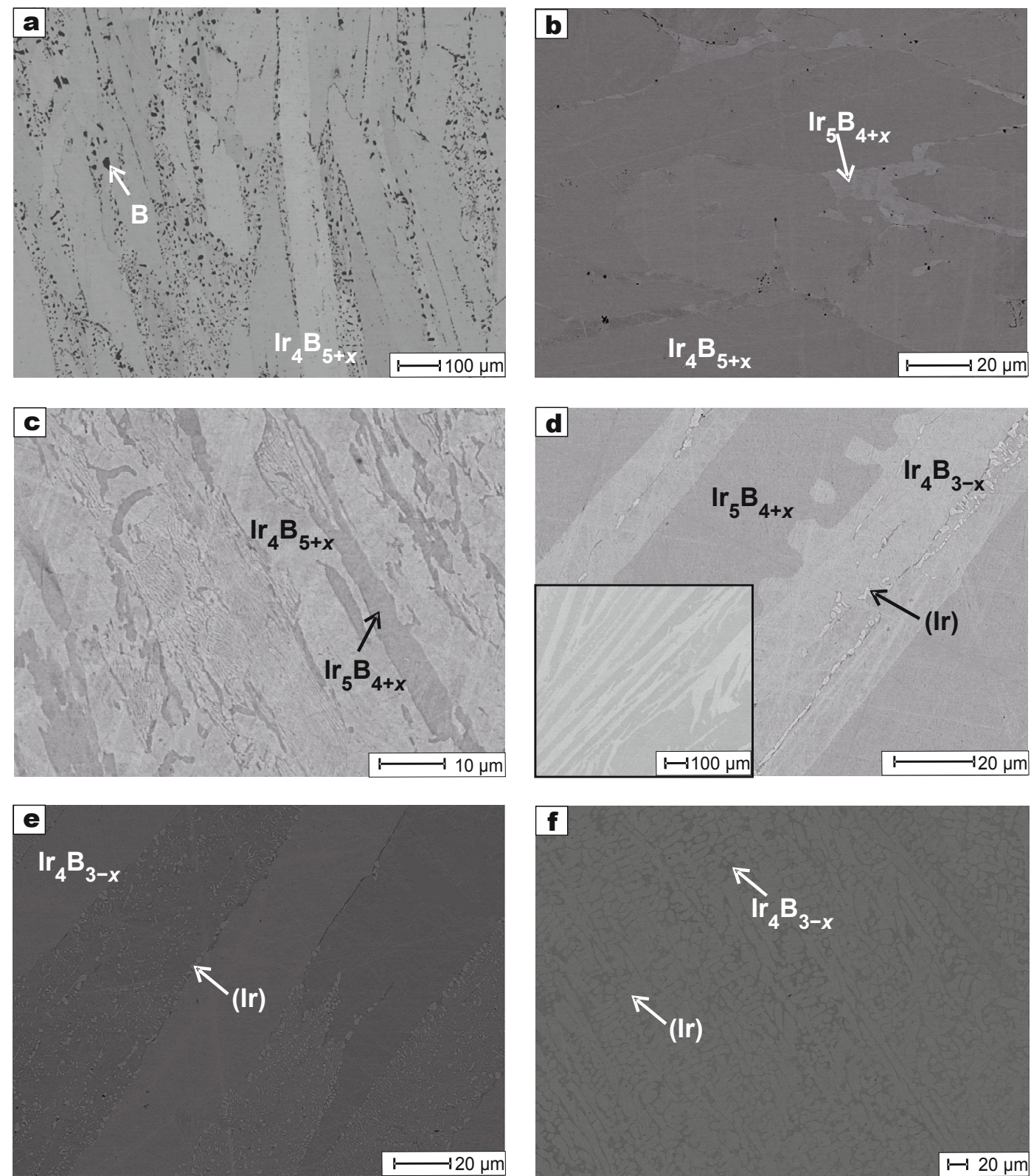

Figure 7 Microstructures of several alloys in as cast state with nominal composition (in at.\%) (a) $\operatorname{Ir}_{42} \mathrm{~B}_{58}$, (b) $\operatorname{Ir}_{47} \mathrm{~B}_{53}$, (c) $\operatorname{Ir}_{52} \mathrm{~B}_{48},\left(\right.$ d) $\operatorname{Ir}_{58} \mathrm{~B}_{42}$, (e) $\operatorname{Ir}_{62} \mathrm{~B}_{38}$ and (f) $\mathrm{Ir}_{90} \mathrm{~B}_{10}$; results from EPMA and XPD for these alloys are summarized in Table 6. 
Table 6 Results from EPMA measurements and X-ray phase analysis for Ir-B alloys in as cast state and/or after annealing; (a)-(f) correspond to the SEM pictures shown in Fig. 7

\begin{tabular}{|c|c|c|c|c|c|c|c|}
\hline \multirow{2}{*}{ Sample } & \multirow{2}{*}{ Phases } & \multirow{2}{*}{$\begin{array}{c}\text { Structure } \\
\text { type }\end{array}$} & \multicolumn{2}{|c|}{ Composition EPMA (at.\%) } & \multicolumn{3}{|c|}{ Lattice parameter (nm) } \\
\hline & & & $\mathrm{Ir}$ & $\mathrm{B}$ & $a$ & $b$ & $c$ \\
\hline $\operatorname{Ir}_{42} B_{58}$ & (B) & B & 0.2 & 99.8 & - & - & - \\
\hline $\begin{array}{l}\text { as cast } \\
\text { (a) }\end{array}$ & $\mathrm{Ir}_{4} \mathrm{~B}_{5+x}$ & $\mathrm{Ir}_{4} \mathrm{~B}_{5}$ & 44.9 & 55.1 & $1.0533(7)$ & $\begin{array}{l}0.29018(1) \\
\beta=91.15(1)\end{array}$ & $0.6100(1)$ \\
\hline \multirow{2}{*}{$\begin{array}{l}\operatorname{Ir}_{47} B_{53} \\
\text { as cast } \\
\text { (b) }\end{array}$} & $\mathrm{Ir}_{4} \mathrm{~B}_{5+x}$ & $\mathrm{Ir}_{4} \mathrm{~B}_{5}$ & 46.0 & 54.0 & $1.0525(2)$ & $\begin{array}{l}0.28982(8) \\
\beta=91.15(7)\end{array}$ & $0.61008(9)$ \\
\hline & $\operatorname{Ir}_{5} B_{4+x}$ & $\mathrm{Ir}_{5} \mathrm{~B}_{4}$ & 53.2 & 46.8 & $0.62741(9)$ & - & $1.0262(2)$ \\
\hline \multirow{2}{*}{$\begin{array}{l}\mathrm{Ir}_{52} \mathrm{~B}_{48} \\
\text { as cast } \\
\text { (c) }\end{array}$} & $\mathrm{Ir}_{4} \mathrm{~B}_{5+x}$ & $\mathrm{Ir}_{4} \mathrm{~B}_{5}$ & 45.8 & 54.2 & $1.0530(1)$ & $\begin{array}{c}0.2894(1) \\
\beta=91.14(1)\end{array}$ & $0.6088(3)$ \\
\hline & $\operatorname{Ir}_{5} B_{4+x}$ & $\mathrm{Ir}_{5} \mathrm{~B}_{4}$ & 52.7 & 47.3 & $0.6279(3)$ & - & $1.0263(3)$ \\
\hline \multirow{2}{*}{$\begin{array}{l}\operatorname{Ir}_{58} B_{42} \\
\text { as cast } \\
\text { (d) }\end{array}$} & $\mathrm{Ir}_{5} \mathrm{~B}_{4+x}$ & $\mathrm{Ir}_{5} \mathrm{~B}_{4}$ & 53.3 & 46.7 & $0.6282(2)$ & & $1.0267(3)$ \\
\hline & $\begin{array}{l}\operatorname{Ir}_{4} B_{3-x} \\
\operatorname{Ir}_{4} B_{3-x} \\
\quad(\mathrm{Ir})\end{array}$ & $\begin{array}{c}\mathrm{WC} \\
\mathrm{Ir}_{4} \mathrm{~B}_{3} \\
\mathrm{Cu}\end{array}$ & $\begin{array}{c}56.8 \\
56.8 \\
100 *\end{array}$ & $\begin{array}{c}43.2 \\
43.2 \\
0\end{array}$ & $\begin{array}{c}- \\
0.27719(2) \\
-\end{array}$ & $\begin{array}{c}- \\
0.7580(2) \\
-\end{array}$ & $\begin{array}{c}- \\
0.73144(9) \\
-\end{array}$ \\
\hline $\begin{array}{l}\operatorname{Ir}_{62} B_{38} \\
\text { as cast } \\
\text { (e) }\end{array}$ & $\begin{array}{l}\mathrm{Ir}_{4} \mathrm{~B}_{3-x} \\
\mathrm{Ir}_{4} \mathrm{~B}_{3-x} \\
\quad(\mathrm{Ir})\end{array}$ & $\begin{array}{c}\mathrm{WC} \\
\mathrm{Ir}_{4} \mathrm{~B}_{3} \\
\mathrm{Cu}\end{array}$ & $\begin{array}{c}58.3 \\
58.3 \\
100 *\end{array}$ & $\begin{array}{c}41.7 \\
41.7 \\
0\end{array}$ & $\begin{array}{c}0.28115(2) \\
0.27717(2) \\
0.3837(3)\end{array}$ & $\begin{array}{c}- \\
0.7580(3) \\
-\end{array}$ & $\begin{array}{c}0.28315(8) \\
0.7315(3) \\
-\end{array}$ \\
\hline $\begin{array}{l}\mathrm{Ir}_{90} \mathrm{~B}_{10} \\
\text { as cast } \\
\quad(\mathrm{f})\end{array}$ & $\begin{array}{c}\operatorname{Ir}_{4} B_{3-x} \\
\operatorname{Ir}_{4} B_{3-x} \\
\text { (Ir) }\end{array}$ & $\begin{array}{c}\mathrm{WC} \\
\mathrm{Ir}_{4} \mathrm{~B}_{3} \\
\mathrm{Cu}\end{array}$ & 58.7 & 41.3 & $\begin{array}{c}0.28137(5) \\
\text { Traces } \\
0.38345(1)\end{array}$ & $\begin{array}{l}- \\
- \\
-\end{array}$ & $\begin{array}{c}0.2828(1) \\
- \\
-\end{array}$ \\
\hline
\end{tabular}

* Fixed values.

reported earlier $\left(1255 \pm 4^{\circ} \mathrm{C}\right.$ at 60 at. $\% \mathrm{~B}[23], 1240 \pm 8^{\circ} \mathrm{C}$ at $\sim 66$ at.\% B [9]) and also the location of the eutectic at $\sim 60$ at. $\%$ B. The $\operatorname{Ir}_{4} \mathrm{~B}_{5+x}$ phase melts congruently at $1288 \pm 4^{\circ} \mathrm{C}$ $\left(1287 \pm 5^{\circ} \mathrm{C}\right.$ [23], $1313 \pm 15^{\circ} \mathrm{C}$ [9], see Table 1). As has been previously reported [13], this compound is not stable at lower temperatures $\left(T \leqslant 1100^{\circ} \mathrm{C}\right)$. Indeed DTA effects document the decomposition at $1083 \pm 10^{\circ} \mathrm{C}$ into $\operatorname{Ir}_{5} \mathrm{~B}_{4+x}$ and boron. Lattice parameters determined in as cast state decrease slightly with decreasing boron content (see Table 6) but are generally $0.01 \AA$ smaller than those reported by Lundström [14]. Thus only a small homogeneity region can be supposed ( 1 at.\% B). The microstructure for the as cast alloy with nominal composition $\operatorname{Ir}_{47} B_{53}$ (Fig. 7b) shows primary grains of $\operatorname{Ir}_{4} \mathrm{~B}_{5+x}$ followed by crystallization of $\operatorname{Ir}_{5} \mathrm{~B}_{4+x}$. A rather fine eutectic like microstructure consisting of $\operatorname{Ir}_{4} B_{5+x}$ and $\operatorname{Ir}_{5} B_{4+x}$ is visible from the alloy $\operatorname{Ir}_{52} \mathrm{~B}_{48}$ in Fig. 7c. Brukl and Rudy [9] determined $1250 \pm 5^{\circ} \mathrm{C}$ as the isothermal reaction temperature for the eutectic $\mathrm{e}_{2}$ : $\mathrm{L} \leftrightarrow \mathrm{Ir}_{4} \mathrm{~B}_{5+x}+\mathrm{Ir}_{5} \mathrm{~B}_{4+x}$ (at $\sim 51$ at.\% B), whereas Ipser and Rogl [23] assigned this temperature to another invariant reaction namely $\mathrm{e}_{3}: \mathrm{L} \leftrightarrow \mathrm{Ir}_{4} \mathrm{~B}_{5+x}+\operatorname{IrB}$ (at 54 at.\% B). In the latter work, the peritectic formation of the IrB phase is reported at $1274 \pm 4^{\circ} \mathrm{C}\left(\mathrm{p}_{1}: \mathrm{L}+\operatorname{Ir}_{5} \mathrm{~B}_{4+x} \leftrightarrow \operatorname{IrB}\right.$ at 50 at. $\%$ B $)$ and a metastable eutectic $\mathrm{e}_{2}: \mathrm{L} \leftrightarrow \mathrm{Ir}_{4} \mathrm{~B}_{5+x}+\mathrm{Ir}_{5} \mathrm{~B}_{4+x}$ at $\sim 1235^{\circ} \mathrm{C}$ has been found instead with the approximate composition $\operatorname{Ir}_{47} \mathrm{~B}_{53}$. The WC structure type has been assigned for IrB, which was described to decompose eutectoidally at $1209 \pm 3^{\circ} \mathrm{C}$ into $\mathrm{Ir}_{5} \mathrm{~B}_{4+x}$ and $\mathrm{Ir}_{5} \mathrm{~B}_{4+x}$. In this investigation, all alloys in the composition range between $\operatorname{Ir}_{53} B_{47}$ to $\operatorname{Ir}_{47} B_{53}$ (in at.\%) exhibit an invariant effect at $1210 \pm 3^{\circ} \mathrm{C}$ followed by several effects close to the afore-mentioned temperatures. As the alloys were investigated in as cast state, after DSC and after annealing at lower temperatures $\left(<1000^{\circ} \mathrm{C}\right)$, no other phase was detected with approximately 50 at.\% boron by XPD or EPMA. The neighbouring boron-rich phase $\operatorname{Ir}_{5} \mathrm{~B}_{4+x}$ forms congruently and melts at $1339 \pm 5^{\circ} \mathrm{C}\left(1333 \pm 5^{\circ} \mathrm{C}\right.$ [23], $1328 \pm 10^{\circ} \mathrm{C}$ [9]). The microstructure of an alloy with nominal composition $\operatorname{Ir}_{58} \mathrm{~B}_{42}$ is shown in Fig. $7 \mathrm{~d}$. Large grains of $\operatorname{Ir}_{5} \mathrm{~B}_{4+x}$ are present (see inset Fig. $7 \mathrm{~d}$ ) together with the $\mathrm{h} T$ and $\ell T$ form of $\operatorname{Ir}_{4} \mathrm{~B}_{3-x}$ (assigned from XPD) and small amounts of ( $\mathrm{Ir}) . \mathrm{Ir}_{4} \mathrm{~B}_{3-x}$ has been reported to melt congruently at $1287 \pm 5^{\circ} \mathrm{C}$ by Ipser and Rogl and at $1270 \pm 20^{\circ} \mathrm{C}$ by Brukl and Rudy. Although the microstructure of the shown as cast alloy gives hints to a peritectic formation of this phase, the results from the DSC measurements confirm the congruent melting at around $1289 \pm 5^{\circ} \mathrm{C}$. Both groups of authors also agree on a eutectic reaction $\mathrm{e}_{4}: \mathrm{L} \leftrightarrow \operatorname{Ir}_{5} \mathrm{~B}_{4+x}+\operatorname{Ir}_{4} \mathrm{~B}_{3-x}$ at $1258 \pm 5^{\circ} \mathrm{C}\left(\sim 40\right.$ at. $\% \mathrm{~B}[23]$ or at $1238 \pm 8^{\circ} \mathrm{C}(\sim 43$ at. $\% \mathrm{~B}$ [9]). Nevertheless, in none of the alloys investigated in this work or in the work of Brukl and Rudy, this eutectic has been observed directly. As argued previously, the eutectic is placed there because of the two neighboring congruent- 
ly melting compounds [9]. The microstructure of an alloy with nominal composition $\operatorname{Ir}_{62} B_{38}$ (Fig. 7e) shows primary grains of $\operatorname{Ir}_{4} \mathrm{~B}_{3-x}$ and a eutectic with (Ir). The invariant reaction temperature for this eutectic $\mathrm{e}_{5}: \mathrm{L} \leftrightarrow(\mathrm{Ir})+\mathrm{Ir}_{4} \mathrm{~B}_{3-x}$ is $1259 \pm 4^{\circ} \mathrm{C}\left(1259 \pm 4^{\circ} \mathrm{C}\right.$ at 37.5 at. $\%$ B [23], $1250 \pm 6^{\circ} \mathrm{C}$ at $\sim 36$ at.\% B [9]). Rogl et al. [16] investigated the $\mathrm{hT}$ and $\ell T$ modification and found above $1200^{\circ} \mathrm{C}$ only the $\mathrm{h} T$ form, in the temperature range 1100 to $1200^{\circ} \mathrm{C}$ both modifications and below $1100^{\circ} \mathrm{C}$ only the $\ell T$ form and therefore suggested a two phase transition. Fig. 7f shows primary grains of (Ir) followed by the crystallization of the same eutectic but almost only the $\mathrm{h} T$ modification of $\operatorname{Ir}_{4} \mathrm{~B}_{3-x}$ (and traces of the $\ell T$ form) is present on the XPD pattern of this alloy in as cast state. From the combination of literature data with new data, the binary Ir-B phase diagram shown in Fig. 8 has been constructed. It should be noted that an earlier investigation of $\operatorname{Ir}_{5} \mathrm{~B}_{4}$ and $\operatorname{Ir}_{4} \mathrm{~B}_{5}$ did not reveal superconductivity in both compounds above $T_{\mathrm{n}}=1.5 \mathrm{~K}$ [46].

\section{Calculated phase stability in the Ir-B system}

Structures, compositions and enthalpies of all compounds in the Ir-B system have also been investigated theoretically through first-principle calculations, coupled with the evolutionary structural search algorithm. We first studied the phase stabilities in the Ir-B system by calculating the formation enthalpy of various compounds $\operatorname{Ir}_{1-x} B_{x}(0<x<1)$ at ambient pressure. The formation enthalpy of the iridium borides was obtained by using the fractional representation $\operatorname{Ir}_{1-x} \mathrm{~B}_{x}(0<x<1)$ with respect to the decomposition into $f c c$-Ir and $\alpha \mathrm{B}$, the ground state phase of elements Ir and $\mathrm{B}$, respectively, as $\Delta H_{\mathrm{f}}\left(\operatorname{Ir}_{1-x} \mathrm{~B}_{x}\right)=E\left(\operatorname{Ir}_{1-x} \mathrm{~B}_{x}\right)-(1-x) E(\mathrm{Ir})-E_{x}(\mathrm{~B})$, where $\Delta H_{\mathrm{f}}$ is the enthalpy of formation per atom and $E$ is the calculated total energy of each compound and each solid metal at its ground state. Fig. 9 summarizes the calculated enthalpy-composition phase diagram of the binary Ir-B system. We have performed the variable composition evolutionary structural search on the Ir-B system at ambient pressure via the USPEX code and obtained the enthalpies of formation (around 2600 compounds) for this system, as presented in Fig. 9a. Stable compositions are determined using the convex hull construction: the convex hull is defined as the line connecting the lowest formation enthalpy

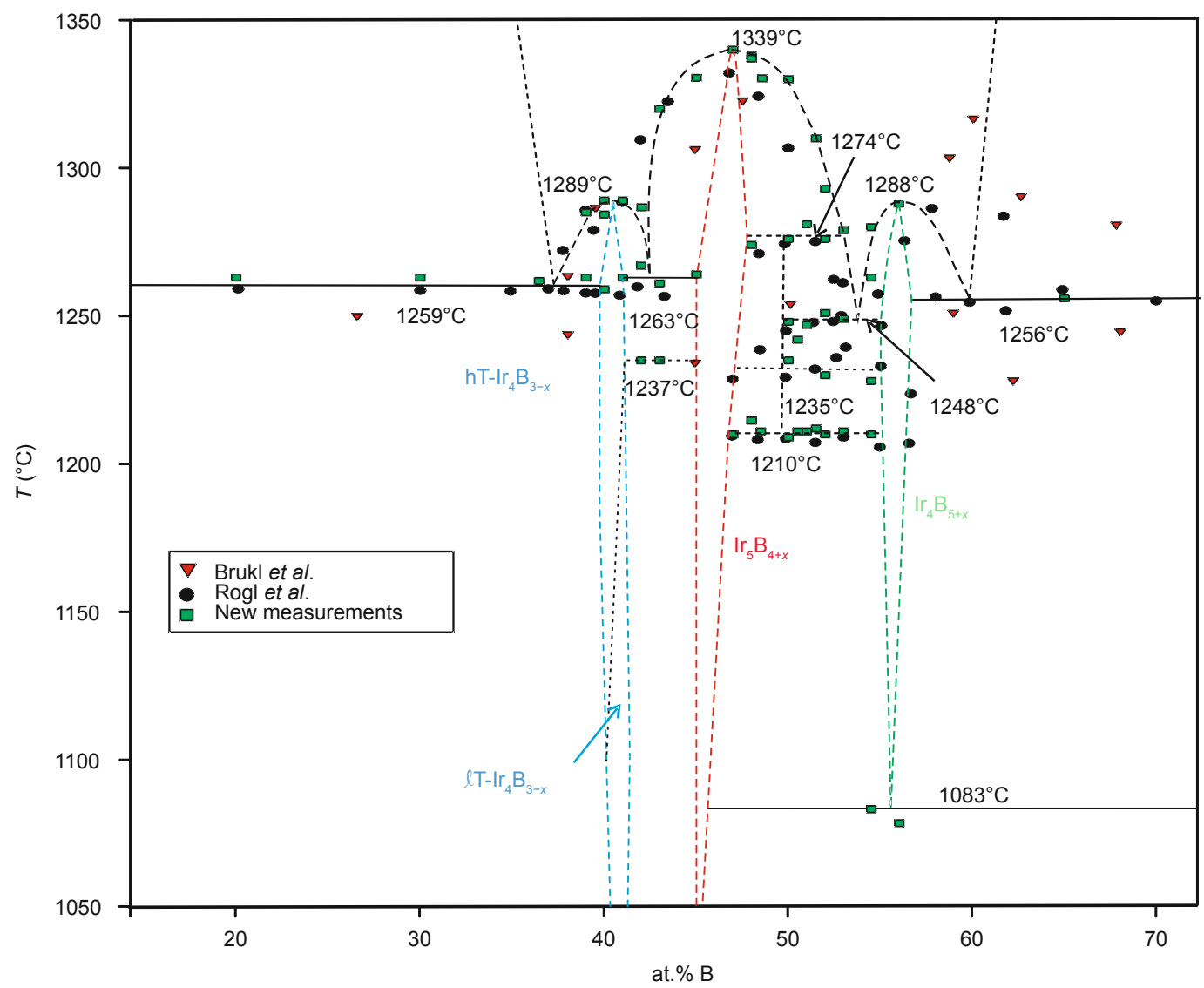

Figure 8 Proposed binary phase diagram Ir-B based on this work and including literature data from Rogl et al. [24] and Brukl et al. [9] above 1050 ${ }^{\circ} \mathrm{C}$. 


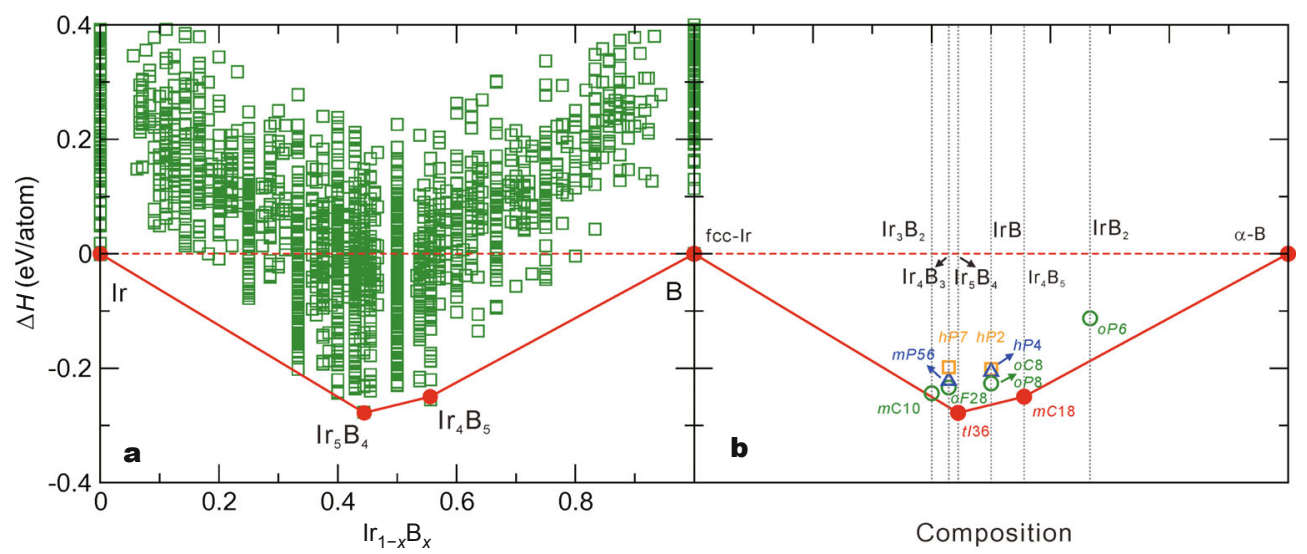

Figure 9 (a) Enthalpies of formation predicted by variable-composition evolutionary computations for the Ir-B system. Each square represents an individual structure and the most stable ground-state phases (solid circles) are connected to form a convex hull. (b) In order to clarify the convex hull, the formation enthalpy is plotted as a function of composition for selected structures of the USPEX-predicted iridium borides, including all the lowest enthalpy ground state phases on the convex hull.

structures at one composition (the red solid line in Fig. 9a), and any structure the formation enthalpy of which lies exactly on the convex hull is deemed as a ground state phase and to be synthesizable in principle. Those structures, for which their enthalpies stay above the convex hull, are thermodynamically metastable and may be synthesized under special conditions. Therefore, from Fig. 9, the compounds $\mathrm{Ir}_{5} \mathrm{~B}_{4}$ and $\mathrm{Ir}_{4} \mathrm{~B}_{5}$ in the structures of $t I 36$ (space group: $I 4_{1} / a$ ) and $m C 18$ (space group: $C 2 / m$ ), respectively, were confirmed to be the ground state phases in the Ir-B binary system as their formation enthalpies lied exactly on the convex hull, which is in perfect agreement with the present experimental characterization. In addition, the dynamical and mechanical stability of these $\operatorname{Ir}-\mathrm{B}$ phases $\left(\operatorname{Ir}_{5} \mathrm{~B}_{4}, \operatorname{Ir}_{4} \mathrm{~B}_{5}, \operatorname{Ir}_{4} \mathrm{~B}_{3}\right.$, $\operatorname{Ir}_{3} B_{2}$ and $\operatorname{IrB}$ ) have been confirmed, as shown in Fig. $S 1$ and Table S3 in the Supplementary information, respectively. It should be noted that the calculated formation enthalpies of the four different structural models of $\mathrm{Ir}_{4} \mathrm{~B}_{5}$ given in Table 3 are nearly the same $(-0.249 \mathrm{eV} /$ atom $)$, indicating that these four structure models are extremely similar. In addition, as most of the experimentally determined structures of the iridium borides reveal defects, we generally build a relative small supercell with a more symmetric atomic pattern to approach the defect-containing structure. The fractional occupation of atoms is usually approximated by a relative simple value: for instance, occupancy of 0.47 is simplified by the value 0.5 . For the Pearson symbol of the defect-containing structures, we used the crystal class and lattice type of the optimized defect-containing structures rather than the original experimental ones. It is noteworthy that the crystallographic space groups would usually reduce after introducing defects. For instance, the space group $C 2 / m$ of
$\mathrm{Ir}_{4} \mathrm{~B}_{5}$ would decrease to a lower one, such as $\mathrm{Cm}$, when a fractional atomic occupation is considered.

For the compound $\mathrm{Ir}_{4} \mathrm{~B}_{3}$, the present experiment proposed three structural models as presented in Table 5. Our calculation found that the $C m c 2_{1}$ phase holds the lowest formation energy compared to the other two structure models ( $\mathrm{Cmcm}$ and Ama2). This fact is in perfect accord with the experimental structure refinements. Furthermore, based on the evolutionary structural search, we have revealed a ground state orthorhombic oF28 phase (space group of Fmm2, Fig. 10d). From DFT calculations this $o$ F28 phase is dynamically stable and lower in energy than either the experimentally claimed one $(h P 7,2 \times 2 \times 1$ highly defect-containing supercell of the WC-type phase) or the low temperature structure $(m P 56,4 \times 1 \times 1$ defect-containing supercell of the $C m c 2_{1}$ phase) by about 0.036 and 0.012 eV/atom, respectively, as shown in Fig. $9 \mathrm{~b}$ and Table 7. For the $o F 28-\mathrm{Ir}_{4} \mathrm{~B}_{3}$ phase, there are two inequivalent $\mathrm{Ir}$ atomic sites at $8 d(0.2489,0,0.3325), 8 b(0.25,0.25,0.0794)$, and two $\mathrm{B}$ atoms stay at $8 c(0,0.2560,0.2415), 4 a(0,0,0)$, respectively. It is interesting to note that the oF28 phase is a layered structure, in which each B atom is equally connected up and down with six Ir atoms forming a boron centered pentahedron. The average Ir-B bond length in the polyhedron is around $2.191 \AA$, whereas the atomic distances of $\mathrm{B}$ and Ir within the same layer are relatively lager, about 2.793 and $2.862 \AA$, respectively.

Besides the verification of the experimental observations on $\operatorname{Ir}_{4} \mathrm{~B}_{5}, \operatorname{Ir}_{5} \mathrm{~B}_{4}$ and $\operatorname{Ir}_{4} \mathrm{~B}_{3}$, we have also investigated several metastable phases at other stoichiometries, such as $\operatorname{Ir}_{3} B_{2}$, IrB and $\operatorname{IrB}_{2}$. The formation enthalpies of these structures with relatively low energy at each composition (near 


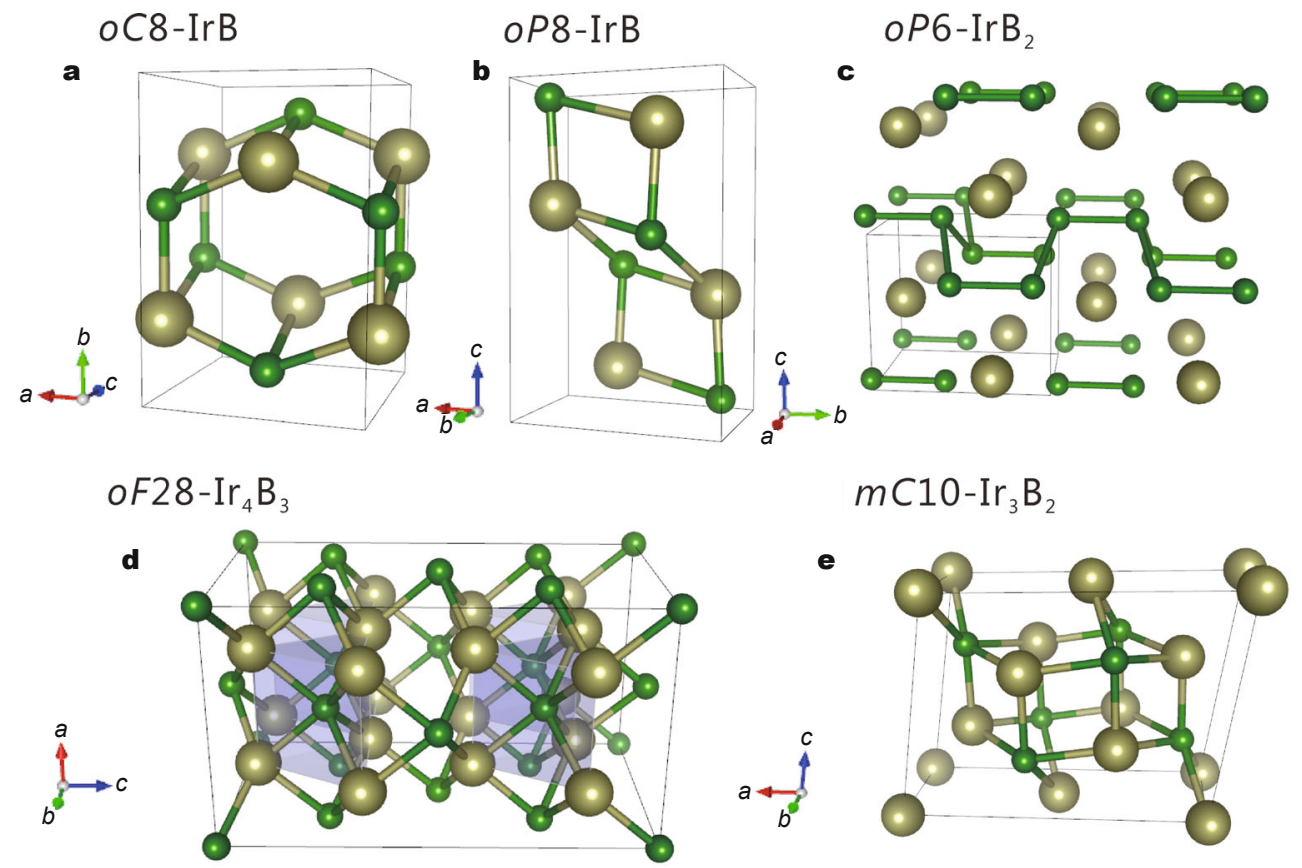

Figure 10 Crystal structures of the predicted iridium borides at ambient pressure. (a) $o C 8$-IrB, (b) $o P 8$-IrB, (c) $o P 6-\operatorname{IrB}_{2}$, (d) $o F 28$-Ir $\mathrm{I}_{4} \mathrm{~B}_{3}$ and (e) $m C 10$ $\mathrm{Ir}_{3} \mathrm{~B}_{2}$. The golden and green spheres represent $\mathrm{Ir}$ and $\mathrm{B}$ atoms, respectively.

to the convex hull) are presented in Fig. $9 \mathrm{~b}$ and their crystal structures are further visualized in Fig. 10. The optimized lattice parameters and atomic sites at ambient pressure are compiled in Table 7.

For the 1:1 stoichiometric $\operatorname{IrB}$, three types of structures ( $h P 2, h P 4$ and $o P 8$ ) have been reported from DFT calculations $[18,19,21]$ to be thermodynamically stable. Interestingly, our present calculation reveals a new ground state phase, $o C 8$ (space group $\mathrm{Cmcm}$ ), which possesses two inequivalent Ir and B Wyckoff atomic sites at $4 c(0,0.2415$, $0.25)$ and $4 c(0,0.6027,0.25)$, respectively, and it is energetically lower than the $h P 2$ and $h P 4$ phases by about 0.022 and $0.020 \mathrm{eV} /$ atom, respectively, as shown in Fig. $9 \mathrm{~b}$ and Table 7. $o$ C8-IrB has nearly the same formation enthalpy as the $o P 8$ phase but both exhibit indeed quite different structures types. As presented in Figs 10a-b, it is clear that both structures are composed of the basic structural units of Ir-B tetragons. However, six Ir-B tetragons with same edge length form two staggered graphite-like rings in the $o C 8$ phase, whilst two Ir-B tetragons and one smaller one constitute a stacked arm-chair chain in the $o P 8$ phase. In addition, for $o C 8$-IrB, the two type Ir-B bonds lengths within the same graphite-like layer are about 2.114 and 2.174 $\AA$, whereas the distance between the adjacent layers is around $2.164 \AA$. In contrast, the $o P 8$ phase holds four different longer Ir-B bonds in the range from 2.154 to $2.405 \AA$.
For the compound $\mathrm{IrB}_{2}$, it is worthy to point out that the two structures oP6 $\left(\mathrm{P}_{5}\right.$ and $\mathrm{OsB}_{2}$-type $)$ reported by Wang et al. [19] are actually identical. In fact, after standardization of crystal data, the $\mathrm{P}_{5}$-phase simplifies to the $\mathrm{OsB}_{2}$-type. Therefore, the most thermodynamically stable phase of $\mathrm{IrB}_{2}$ is the $\mathrm{OsB}_{2}$-type $o P 6$ phase, as shown in Fig. $10 \mathrm{c}$ and Table 7. In one unit cell of $o P 6-\mathrm{IrB}_{2}$, each two boron atoms form dimers within the atomic distance of $1.810 \AA$, which is comparable to the ones in $\mathrm{RuB}_{2}$ and $\mathrm{OsB}_{2}$, and these boron dimers would compose arm-chair chains if projected along the $a$-axis (see Fig. 10c).

Our structural prediction also reveals one never reported stoichiometry, $\operatorname{Ir}_{3} \mathrm{~B}_{2}$, which is the composition nearest to the convex-hull among these metastable compounds $\operatorname{Ir}_{4} \mathrm{~B}_{3}, \operatorname{IrB}$ and $\operatorname{IrB}_{2}$, as shown in Fig. 9b. The $m C 10-\operatorname{Ir}_{3} \mathrm{~B}_{2}$ is a monoclinic phase in the space group of $C 2 / \mathrm{m}$ with two inequivelant Ir atomic sites at $2 a(0,0,0)$ and $4 i(0.3333,0$, $0.3352)$, respectively, and the $\mathrm{B}$ atoms reside at $4 i(0.6155$, $0,0.2786)$. This phase resides only about $0.006 \mathrm{eV} /$ atom above the convex hull. From Fig. 10e, $m C 10-\mathrm{Ir}_{3} \mathrm{~B}_{2}$ can be considered as a combination of one Ir atomic layer and a double layer of graphite-like Ir/B rings. This double layer graphite-like ring is highly analogous to that in the $o C 8$ IrB phase (Fig. 10b), except for that only the former one is distorted. The $\mathrm{Ir}-\mathrm{B}$ distances within one layer are about 2.155 and $2.193 \AA$, which are relatively larger than in the 
Table 7 Calculated crystallographic details of structures of the Ir-B system. The list presents the total energy (eV/atom), the formation energy (eV/ atom), the optimized equilibrium lattice parameters $(a, b$ and $c(\mathrm{~nm}))$, and the atomic sites of Ir-B phases at ambient pressure.

\begin{tabular}{|c|c|c|c|c|c|c|c|c|c|}
\hline \multirow{2}{*}{ Phases } & \multirow{2}{*}{$\begin{array}{c}\text { Pearson } \\
\text { symbol }\end{array}$} & \multirow{2}{*}{ Space group } & \multirow{2}{*}{$\begin{array}{c}\text { Total energy } \\
\text { (eV/atom) }\end{array}$} & \multirow{2}{*}{$\begin{array}{c}\text { Formation } \\
\text { energy } \\
\text { (eV/atom) }\end{array}$} & \multirow{2}{*}{$\begin{array}{c}\text { Lattice } \\
\text { parameters }\end{array}$} & \multicolumn{4}{|c|}{ Atomic sites } \\
\hline & & & & & & & $x$ & $y$ & $z$ \\
\hline $\mathrm{Ir}$ & $c F 4$ & $F m \overline{3} m$ & -8.8488 & & $a=0.38722$ & $\mathrm{Ir}$ & 0 & 0 & 0 \\
\hline \multirow[t]{2}{*}{ B } & $h R 36$ & $R \overline{3} m$ & -6.6780 & & $a=0.49002$ & $\mathrm{~B} 1$ & 0.4521 & 0.5479 & 0.0582 \\
\hline & & & & & $c=1.25525$ & B2 & 0.5302 & 0.4698 & 0.1909 \\
\hline \multirow[t]{9}{*}{$\mathrm{Ir}_{4} \mathrm{~B}_{5}$} & $m C 18$ & $\mathrm{Cm}$ & -7.8926 & -0.24973 & $a=1.06220$ & Ir1 & 0.0336 & 0 & 0.1341 \\
\hline & & (defective $C 2 / m$ ) & & & $b=0.29048$ & Ir2 & -0.0693 & 0 & 0.2865 \\
\hline & & & & & $c=1.21648$ & Ir3 & -0.0434 & 0 & 0.8574 \\
\hline & & & & & $\beta=149.709^{\circ}$ & $\operatorname{Ir} 4$ & 0.0660 & 0 & 0.7067 \\
\hline & & & & & & $\mathrm{B} 1$ & 0.1744 & 0 & 0.6142 \\
\hline & & & & & & B2 & 0.2844 & 0 & 0.4624 \\
\hline & & & & & & B3 & -0.1713 & 0 & 0.3838 \\
\hline & & & & & & B4 & -0.2797 & 0 & 0.5386 \\
\hline & & & & & & B5 & -0.6959 & 0 & 0.0454 \\
\hline \multirow[t]{3}{*}{$\mathrm{Ir}_{5} \mathrm{~B}_{4}$} & $t I 36$ & $I 4_{1} / \mathrm{a}$ & -8.162 & -0.27793 & $a=0.63272$ & $\operatorname{Ir} 1$ & 0.1063 & 0.0487 & 0.3802 \\
\hline & & & & & $c=1.03625$ & Ir 2 & 0 & 0.25 & 0.125 \\
\hline & & & & & & B1 & 0.2882 & 0.1577 & 0.0338 \\
\hline \multirow[t]{35}{*}{$\mathrm{Ir}_{4} \mathrm{~B}_{3}$} & $o F 28$ & $F m m 2$ & -8.1522 & -0.23368 & $a=0.56583$ & Ir1 & 0.2489 & 0 & 0.3325 \\
\hline & & & & & $b=0.57244$ & $\operatorname{Ir} 2$ & 0.25 & 0.25 & 0.0794 \\
\hline & & & & & $c=1.00269$ & B1 & 0 & 0.2560 & 0.2415 \\
\hline & & & & & & B2 & 0 & 0 & 0 \\
\hline & $m P 56$ & $P 2_{1}$ & -8.14043 & -0.22191 & $a=0.75776$ & $\operatorname{Ir} 1$ & 0.0008 & 0.0000 & 0.4992 \\
\hline & & $(4 \times 1 \times 1 \quad$ defective & & & $b=0.74335$ & Ir 2 & 0.2693 & 0.2557 & 0.5030 \\
\hline & & supercell of $C m c 2_{1}$ ) & & & $c=1.14892$ & Ir3 & 0.5029 & 0.0078 & 0.3664 \\
\hline & & & & & $\beta=90.434^{\circ}$ & $\operatorname{Ir} 4$ & 0.2278 & 0.7576 & 0.3634 \\
\hline & & & & & & Ir7 & 0.5007 & 0.0049 & 0.6211 \\
\hline & & & & & & $\operatorname{Ir} 8$ & 0.7721 & 0.2577 & 0.3715 \\
\hline & & & & & & Ir9 & 0.0073 & 0.0150 & 0.2496 \\
\hline & & & & & & $\operatorname{Ir} 10$ & 0.2678 & 0.2653 & 0.7557 \\
\hline & & & & & & $\operatorname{Ir} 11$ & 0.5100 & 0.0116 & 0.1222 \\
\hline & & & & & & $\operatorname{Ir} 12$ & 0.2364 & 0.7632 & 0.1243 \\
\hline & & & & & & $\operatorname{Ir} 13$ & 0.0067 & 0.5067 & 0.2509 \\
\hline & & & & & & $\operatorname{Ir} 14$ & 0.2841 & 0.2608 & 0.2403 \\
\hline & & & & & & $\operatorname{Ir} 15$ & 0.5090 & 0.5041 & 0.1244 \\
\hline & & & & & & $\operatorname{Ir} 16$ & 0.7893 & 0.2623 & 0.1215 \\
\hline & & & & & & $\operatorname{Ir} 17$ & 0.0009 & 0.0091 & 0.0050 \\
\hline & & & & & & $\operatorname{Ir} 18$ & 0.7221 & 0.7571 & 0.0085 \\
\hline & & & & & & $\mathrm{B} 1$ & 0.2855 & 0.5560 & 0.5029 \\
\hline & & & & & & B2 & 0.2235 & 0.0514 & 0.3673 \\
\hline & & & & & & B4 & 0.2173 & 0.0529 & 0.6320 \\
\hline & & & & & & B5 & 0.2957 & 0.5538 & 0.2423 \\
\hline & & & & & & B6 & 0.2003 & 0.0567 & 0.8747 \\
\hline & & & & & & B7 & 0.2763 & 0.5481 & 0.0007 \\
\hline & & & & & & B13 & 0.5619 & 0.2816 & 0.5076 \\
\hline & & & & & & B14 & 0.0589 & 0.2860 & 0.6392 \\
\hline & & & & & & $\mathrm{B} 16$ & 0.0610 & 0.2642 & 0.3642 \\
\hline & & & & & & B17 & 0.5714 & 0.2409 & 0.2403 \\
\hline & & & & & & B18 & 0.0742 & 0.2400 & 0.1147 \\
\hline & & & & & & B19 & 0.4406 & 0.7681 & 0.0018 \\
\hline & $h P 7$ & $P \overline{6} m 2$ & -8.1166 & -0.19808 & $a=0.57072$ & Ir1 & 0.50422 & 0.49578 & 0 \\
\hline & & $(2 \times 2 \times 1$ defective & & & $c=0.28680$ & Ir2 & 0 & 0 & 0 \\
\hline & & supercell of $P \overline{6} m 2$ ) & & & & $\mathrm{B} 1$ & 0.17661 & 0.82339 & 0.5 \\
\hline
\end{tabular}

(To be continued on the next page) 


\begin{tabular}{|c|c|c|c|c|c|c|c|c|c|}
\hline \multirow{2}{*}{ Phases } & \multirow{2}{*}{$\begin{array}{l}\text { Pearson } \\
\text { symbol }\end{array}$} & \multirow{2}{*}{ Space group } & \multirow{2}{*}{$\begin{array}{c}\text { Total energy } \\
\text { (eV/atom) }\end{array}$} & \multirow{2}{*}{$\begin{array}{c}\text { Formation } \\
\text { energy } \\
\text { (eV/atom) }\end{array}$} & \multirow{2}{*}{$\begin{array}{c}\text { Lattice } \\
\text { parameters }\end{array}$} & \multicolumn{4}{|c|}{ Atomic sites } \\
\hline & & & & & & & $x$ & $y$ & $z$ \\
\hline \multirow[t]{3}{*}{$\mathrm{Ir}_{3} \mathrm{~B}_{2}$} & $m C 10$ & $\mathrm{C} 2 / \mathrm{m}$ & -8.22422 & -0.24368 & $a=0.75109$ & Ir 1 & 0.3333 & 0 & 0.3352 \\
\hline & & & & & $b=0.28521$ & Ir 2 & 0 & 0 & 0 \\
\hline & & & & & $c=0.56566$ & $\mathrm{~B} 1$ & 0.6155 & 0 & 0.2786 \\
\hline \multirow[t]{8}{*}{$\operatorname{IrB}$} & $o C 8$ & $\mathrm{Cmcm}$ & -7.990 & -0.22653 & $\begin{array}{l}\beta=99.612^{\circ} \\
a=0.40331\end{array}$ & $\mathrm{Ir}$ & 0 & 0.24156 & 0.25 \\
\hline & & & & & $\begin{array}{l}b=0.58558 \\
c=0.39247\end{array}$ & B & 0 & 0.60269 & 0.25 \\
\hline & $o P 8$ & Pnma & -7.990 & -0.22653 & $a=0.44246$ & Ir & 0.1540 & 0.25 & 0.3669 \\
\hline & & & & & $\begin{array}{l}b=0.28737 \\
c=0.70030\end{array}$ & B & 0.1268 & 0.25 & 0.0496 \\
\hline & $h P 4$ & $P 6_{3} / m m c$ & -7.9696 & -0.20613 & $a=0.3512$ & Ir & 0.3333 & 0.6666 & 0.25 \\
\hline & & & & & $c=0.3963$ & B & 0 & 0 & 0 \\
\hline & $h P 2$ & $P \overline{6} m 2$ & -7.9678 & -0.20433 & $a=0.3047$ & $\mathrm{Ir}$ & 0 & 0 & 0 \\
\hline & & & & & $c=0.2718$ & B & 0.3333 & 0.6666 & 0.25 \\
\hline \multirow[t]{3}{*}{$\mathrm{IrB}_{2}$} & $o P 6$ & Pmmn & -7.5145 & -0.11282 & $a=0.31547$ & Ir & 0.25 & 0.25 & 0.6644 \\
\hline & & & & & $b=0.45398$ & B & 0.25 & 0.0506 & 0.1502 \\
\hline & & & & & $c=0.40382$ & & & & \\
\hline
\end{tabular}

$o C 8$ phase and the distance between the adjacent layers is slightly shorter, around $2.154 \AA$ in the $m C 10$ phase.

\section{CONCLUSIONS}

The binary system Ir-B has been investigated in the composition range between 10 and 70 at.\% boron. Four binary phases were found namely $\operatorname{Ir}_{4} \mathrm{~B}_{5+x}, \operatorname{Ir}_{5} \mathrm{~B}_{4+x}$ and the high and low temperature modification of $\operatorname{Ir}_{4} \mathrm{~B}_{3-x}$. X-ray single crystal diffraction studies were performed on $\operatorname{Ir}_{4} \mathrm{~B}_{5+x}(x=0$, $\mathrm{Ir}_{4} \mathrm{~B}_{5}$ structure type; space group $C 2 / m ; a=1.05200(2), b=$ $0.289564(6)$ and $\left.c=0.60958(1) \mathrm{nm}, \beta=91.156(2)^{\circ}\right), \operatorname{Ir}_{5} \mathrm{~B}_{4+x}$ $\left(x=0, \operatorname{Ir}_{5} \mathrm{~B}_{4}\right.$ structure type; space group $I 4_{1} / a ; a=0.62777(1)$ and $b=1.02599(2) \mathrm{nm})$ and on the low temperature modification of $\operatorname{Ir}_{4} \mathrm{~B}_{3-x}\left(x=0, \operatorname{IrB}_{0.9}\right.$ structure type; space group $\mathrm{Cmc2}_{1} ; a=0.27728(1), b=0.75742(2)$ and $c=0.73152(2)$ $\mathrm{nm}) . \mathrm{Ir}_{5} \mathrm{~B}_{4+x}(x=0)$ crystallizes with a new and fully ordered $a-\mathrm{ThSi}_{2}$ derivative structure type. The high temperature modification of $\operatorname{Ir}_{4} \mathrm{~B}_{3-x}$ (WC structure type; space group $P \overline{6} m 2 ; a=0.28137(5)$ and $c=0.2828(1) \mathrm{nm}$ ) was confirmed by XRD. The binary Ir-B phase diagram was constructed combining results from XPD, EPMA and DSC with literature data. Our first-principle calculations further confirmed the experimental observations on $\operatorname{Ir}_{4} \mathrm{~B}_{5}, \mathrm{Ir}_{5} \mathrm{~B}_{4}$ and $\mathrm{Ir}_{4} \mathrm{~B}_{3}$, and defined $m C 18-\mathrm{Ir}_{4} \mathrm{~B}_{5}$ and $t 136-\mathrm{Ir}_{5} \mathrm{~B}_{4}$ to be the only two ground state phases of the Ir-B system. In combination with the evolutionary structural search algorithm, we also investigated the crystal structures of several metastable phases at other stoichiometries, such as $\operatorname{IrB}, \operatorname{IrB}_{2}, \operatorname{Ir}_{3} B_{2}$. In addition, we found three new thermodynamically stable structures: $o F 28-\mathrm{Ir}_{4} \mathrm{~B}_{3}, o C 8$ - $\mathrm{IrB}$ and $m C 10-\mathrm{Ir}_{3} \mathrm{~B}_{2}$, which may be synthesizable under certain conditions.

Received 16 July 2015; accepted 13 August 2015; published online 24 August 2015

1 Ivanovskii AL. The search for novel superhard and incompressible materials on the basis of higher borides of s, p, d metals. J Superhard Mater, 2011, 33: 73-87

2 Gu Q, Krauss G, Steurer W. Transition metal borides: superhard versus ultra incompressible. Adv Mater, 2008, 20: 3620-3626

3 Chung HY, Yang JM, Weinberger MB, et al. Synthesis of ultraincompressible superhard rhenium diboride at ambient pressure. Science, 2007, 316: 436-439

4 Zeiringer I, Rogl P, Polt J, et al. Crystal structure of $\mathrm{W}_{1-x} \mathrm{~B}_{3}$ and phase equilibria in the boron-rich part of the systems Mo-Rh-B and $\mathrm{W}-\{\mathrm{Ru}, \mathrm{Os}, \mathrm{Rh}, \mathrm{Ir}, \mathrm{Ni}, \mathrm{Pd}, \mathrm{Pt}\}-\mathrm{B}$. J Phase Equilib and Diff, 2014, 35 : 384-395

5 Rau JV, Latini A. New hard and superhard materials: $\mathrm{RhB}_{1.1}$ and IrB $_{1.35}$. Chem Mater, 2009, 21: 1407-1409

6 Latini A, Rau JV, Teghil R, Generosi A, Albertini VR. Superhard properties of rhodium and iridium boride films. J Appl Mater Interfaces, 2010, 2: 581-587

7 Buddery JH, Welch AJE. Borides and silicides of the platinum metals. Nature, 1951, 167: 362

8 Samsonov GV, Kosenko VA, Rud' BM, Sidorova VG. Preparation and properties of the compound $\mathrm{IrB}_{1.1}$. Inorg Mater, 1972, 8: $671-672$

9 Brukl CE, Rudy E. Ternary Phase Equilibria in the Transition-Metal-Boron-Carbon-Silicon System. Air Force Materials Laboratory Technical Report (AFML-TR-65-2), 1967, 14: 31-42

10 Reinacher G. Hot-stage microscope determination of the solidus temperatures of iridium alloys with about $1 \mathrm{wt}$ \% boron, phosphorus or silicon. Metall, 1965, 19: 707-711

11 Kosenko VA, Zhidkova TG. Synthesis and some chemical properties of iridium boride $\operatorname{IrB}_{1.1}$. Ukr Khim Zh, 1974, 40: 18-20

12 Aronsson B, Stenberg E, Åselius J. Borides of rhenium and the platinum metals. The crystal structure of $\operatorname{Re}_{7} B_{3}, \operatorname{ReB}_{3}, \mathrm{Rh}_{7} \mathrm{~B}_{3}, \mathrm{RhB}_{1.1}$ (ap- 
proximate composition), $\mathrm{IrB}_{1.1}$ (approximate composition) and $\mathrm{PtB}$. Acta Chem Scand, 1960, 14: 733-741

13 Aronsson $\mathrm{B}$. The crystal structure of $\mathrm{RuB}_{2}, \mathrm{OsB}_{2}$ and $\mathrm{IrB}_{1.35}$ and some general comments on the crystal chemistry of borides in the composition range $\mathrm{MeB}-\mathrm{MeB}_{3}$. Acta Chem Scand, 1963, 17: 2036-2050

14 Lundström T, Tergenius LE. Refinement of the crystal structure of the non-stoichiometric moride $\mathrm{IrB}_{1.35}$ (approximate composition). Acta Chem Scand, 1973, 27: 3705-3711

15 Haschke H. Structural Chemical Investigations on Complex Borides and Carbides, as well as on Silicides and Germanides of Rare Earth Metals. Dissertation for Doctoral Degree. University of Vienna, 1966.

16 Rogl P, Nowotny H, Benesovsky F. Ein Beitrag zur Strukturchemie der Iridiumboride. Monatshefte für Chemie, 1971, 102: 678-686 (in Germany)

17 Vandenberg JH, Matthias BT, Corenzwit E, Barz H. Superconductivity of some binary and ternary transition metal borides. Mat Res Bull, 1975, 10: 889-894

18 Zhao WJ, Wang JX. Structural, mechanical, and electronic properties of $\mathrm{TaB}_{2}, \mathrm{TaB}, \mathrm{IrB}_{2}$, and IrB: first-principle calculations. J Solid State Chem, 2009, 182: 1280-1286

19 Wang DY, Wang B, Wang XY. New crystal structures of IrB and $\mathrm{IrB}_{2}$ : first-principles calculations. J Phys Chem C, 2012, 116: 21961-21966

20 Hao X, Wu Z, Xu Y, et al. Trends in elasticity and electronic structure of $5 \mathrm{~d}$ transition metal diborides: first-principles calculations. J Phys Condens Matter, 2007, 19: 196212

21 Wang Y, Chen W, Chen X, et al. Crystal structures, stability, electronic and elastic properties of $4 \mathrm{~d}$ and $5 \mathrm{~d}$ transition metal monoborides: first-principles calculations. J Alloys Compd, 2012, 538: $115-124$

22 Spear KE. Correlations and Predictions of Metal-Boron Phase Equilibria. In Proceedings of a Workshop held in Gaithersburg 1977. US Dep Commerce, Natl Bur Stand, Spec Publ SP-496/2, 1978, 744-762

23 Ipser H, Rogl P. Constitution diagrams of the binary systems Pd-B and Ir-B. J Less-Common Metals, 1981, 82: 362

24 Rogl P, Effenberg G (eds.). Phase Diagrams of Ternary Metal-Boron-Carbon Systems. Ohio: ASM International, 1988, 150-153

25 Zivkovic D, Stuparevic L. Calculations of the thermodynamic properties in the Ir-B system based on the known phase diagram. RMZMaterials and Geoenvironmen, 2005, 52: 463-468

26 Meschel SV, Kleppa OJ. Enthalpies of formation of refractory borides of $5 \mathrm{~d}$ elements by high temperature direct synthesis calorimetry: $\mathrm{IrB}_{1.35}$ and $\mathrm{OsB}_{2.5}$. J Alloys Compd, 1991, 177: 159-166

27 Van der Auwera-Mahieu A, Peeters R, McIntyre NS, Drowart J. Mass spectrometric determination of dissociation energies of the borides and silicides of some transition metals. Trans Faraday Soc, 1970, 66: 809-816

28 Rodriguez-Carvajal J. Recent developments of the program FULLPROF. Physica B, 1993, 55: 192

29 Sheldrick GM. SHELXS-97. Acta Cryst, 1990, A46: 467-473

30 Sheldrick GM. Program SHELX-97 for Crystal Structure Determination. University of Goettingen, 1997

31 Farrugia LJ. WINGX suite for small-molecule single-crystal crystallography. J Appl Cryst, 1999, 32: 837-838

32 Gelato LM, Parthé E. STRUCTURE TIDY-a computer program to standardize crystal structure data. J Appl Cryst, 1987, 20: 139-143

33 Hohenberg P, Kohn W. Inhomogeneous electron gas. Phys Rev B,

\section{4, 136: 864}

34 Kohn W, Sham LJ. Self-consistent equations including exchange and correlation effects. Phys Rev A, 1965, 140: 1133

35 Kresse G, Hafner J. Ab initio molecular dynamics for liquid metals. Phys Rev B, 1993, 47: 558-561

36 Kresse G, Furthmüller J. Efficiency of ab-initio total energy calculations for metals and semiconductors using a plane-wave basis set. Comput Mat Sci, 1996, 6: 15-50

37 Blöchl PE, Jepsen O, Andersen OK. Improved tetrahedron method for Brillouin-zone integrations. Phys Rev B, 1994, 23: 16223

38 Perdew JP, Burke K, Ernzerhof M. Generalized gradient approximation made simple. Phys Rev Lett, 1996, 77: 3865

39 Togo A, Oba F, Tanaka I. First-principles calculations of the ferroelastic transition between rutile-type and $\mathrm{CaCl}_{2}$-type $\mathrm{SiO}_{2}$ at high pressures. Phys Rev B, 2008. 78: 134106

40 Oganov AR, Glass CW. Crystal structure prediction using ab initio evolutionary techniques: principles and applications. J Chem Phys, 2006, 124: 244704

41 Oganov AR, Lyakhov AO, Valle M. How evolutionary crystal structure prediction works-and why. Acc Chem Res, 2011, 44: 227-237

42 Crespo AJ, Tergenius LE, Lundström T. The solid solution of $4 \mathrm{~d}, 5 \mathrm{~d}$ and some p-elements in $\beta$-rhombohedral boron. J Less-Common Metals, 1981, 77: 147-150

43 Rogl P. Existence and Crystal Chemistry of Borides, in Inorganic Reactions and Methods: Formation of Bonds to Group-I, -II, and -IIIB Elements. Hoboken: John Wiley \& Sons Inc, 1991, 13: 85-167

44 Teatum E, Gschneidner K, Waber J, Pearson WB (eds.). The Crystal Chemistry and Physics of Metals and Alloys. New York: Wiley-Interscience, 1972

45 Bärnighausen H. Group-subgroup relations between space groups: a useful tool in crystal chemistry. Commun Math Chem, 1980, 9: 139

46 Rogl P, DeLong L. New ternary transition metal borides containing uranium and rare earth elements. J Less-Common Metals, 1983, 91: 97-106

47 Villars P, Cenzual K. Pearson's Crystal Data CD-ROM. ASM International, Ohio, Release 2013/14

Acknowledgements This work was supported by Austrian Science Fund FWF under P22295. All EPMA measurements were carried out in the Faculty Centre for Nanostructure Research at the University of Vienna. Especially, we thank Dr. Puchegger for his help with SEM. This work was also partially supported by the 'Hundred Talents Project' of Chinese Academy of Sciences and the Key Research Program of Chinese Academy of Sciences (KGZD-EW-T06) and the National Natural Science Foundation of China (NSFC) (51074188 and 51474202). The computational resource is using the local HPC cluster of the Materials Process Modeling Division at the Institute of Metal Research (IMR) as well as the National Supercomputing Center in Tianjin (TH-1A system).

Author Contributions Rogl PF and Chen XQ conceived the idea. Zeiringer I and Cheng XY performed the experiments and calculations, respectively, and should be regarded as co-first authors. Zeiringer I, Cheng XY, Chen XQ, Bauer E, Giester G and Rogl PF wrote the manuscript with contribution from all.

Conflict of Interests The authors declare that they have no conflict of interest.

Supplementary information Supporting data are available in the online version of the paper. 

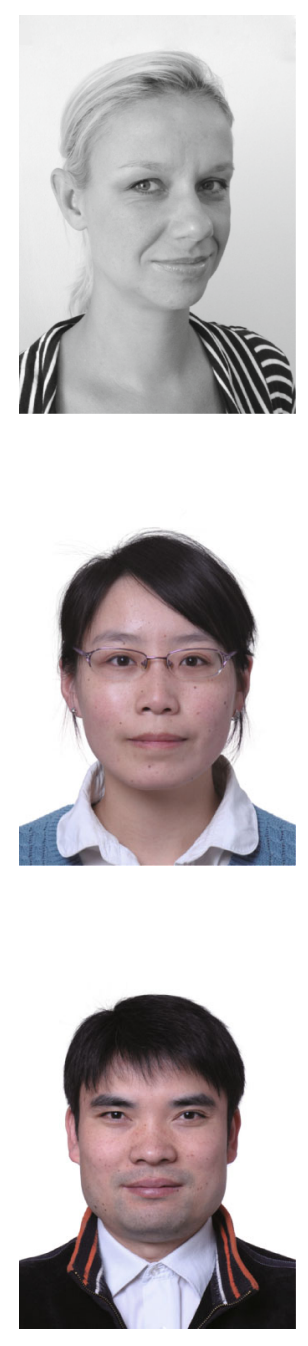

Xiyue Cheng was born in Kangding, Sichuan Province, China. She received her BSc degree from Central South University in 2011. Now she is a PhD candidate in the group of computational materials design at the Institute of Metal Research, Chinese Academy of Sciences. Her research interest focuses on high-throughput computational material design in the aspect of high-performance metallic borides.
Isolde Zeiringer received her $\mathrm{PhD}$ degree in chemistry based on her thesis "Non-centrosymmetric Superconductors", which was performed in the Institute of Physical Chemistry at the University of Vienna. Part of her thesis was performed at the research laboratory in Div. Bajas Temperaturas, CAB-CNEA, Bariloche, Argentina. Currently she has published eleven peer-review papers.
Xing-Qiu Chen obtained his PhD degree in computational materials science at the University of Vienna in 2004 and completed the postdoctoral studies at Vienna Center of Computational Materials Science and Oak Ridge National Laboratory from 2005 to 2010 . He is currently a professor at Shenyang National Laboratory for Materials Science funded by Hundred Talent Project. His research interests mainly focus on the computational material design on high-performance structural materials and strongly-correlated metallic alloys.

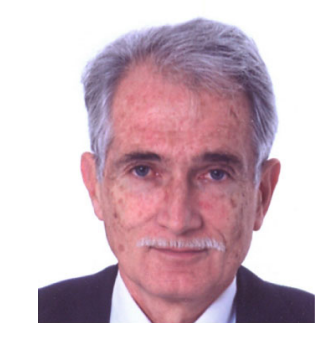

Peter Franz Rogl holds PhD degree in physics from the University of Vienna (1971) and venia docendi in physical chemistry (1980). Since 2004, he is a full professor at the chair of Physical Chemistry of Materials (Univ. Vienna). He won Sandoz research award of Sandoz Research Center in 1985; Felix Kuschenitz Price of Austrian Academy of Sciences for outstanding research in 1992. He has authored/co-authored more than 600 peer-review papers in journals and 22 books or chapters in books.

中文摘要本文通过差示扫描量热法、电子探针以及等温低温退火处理, 系统地研究了铱硼二元体系在B元素含量 $10 \%$ 70\%范围内 化合物的结构及组成, 并成功的合成及表征了四种化合物: $\operatorname{Ir}_{4} \mathrm{~B}_{5+x}, \operatorname{Ir}_{5} \mathrm{~B}_{4+x}$ 以及 $\operatorname{Ir}_{4} \mathrm{~B}_{3-\mathrm{x}}$ 的高温和低温相. 运用单晶X射线衍射法确定了 $\mathrm{Ir}_{4} \mathrm{~B}_{5+x}\left(x=0, \mathrm{Ir}_{4} \mathrm{~B}_{5}\right.$ 型; 空间群 $\left.C 2 / m ; a=1.05200(2), b=0.289564(6), c=0.60958(1) \mathrm{nm}, \beta=91.156(2)^{\circ}\right), \operatorname{Ir}_{5} \mathrm{~B}_{4+x}\left(x=0, \operatorname{Ir}_{5} \mathrm{~B}_{4}\right.$ 型; 空间群 $\left.I 4_{1} / a ; a=0.62777(1), b=1.02599(2) \mathrm{nm}\right)$ 以及 $\operatorname{Ir}_{4} \mathrm{~B}_{3-x}$ 低温相 $\left(x=0, \operatorname{IrB}_{0.9}\right.$ 型; 空间群 $C m c 2_{1} ; a=0.27728(1), b=0.75742(2), c=0.73152(2)$ $\mathrm{nm}$ ) 的晶格常数及结构. 运用粉末X射线衍射法确定了 $\operatorname{Ir}_{4} \mathrm{~B}_{3-x}$ 高温相 (WC型; 空间群 $P \overline{6} m 2 ; a=0.28137(5), c=0.2828(1) \mathrm{nm}$ ) 的晶格常数 及结构. 通过第一性原理计算结合结构演化搜索方法, 从理论上研究了该体系的组成、结构以及相稳定性. 除了验证实验合成的 $\mathrm{Ir}_{4} \mathrm{~B}_{5}$ 、 $\mathrm{Ir}_{5} \mathrm{~B}_{4}$ 以及 $\mathrm{Ir}_{4} \mathrm{~B}_{3}$, 本文还预测了三个可能在一定条件下合成的新稳定结构: $o F 28-\mathrm{Ir}_{4} \mathrm{~B}_{3}, o C 8-\operatorname{IrB}$ 以及 $m C 10-\mathrm{Ir}_{3} \mathrm{~B}_{2}$. 